\title{
Elevated trace elements in sediments and seagrasses at $\mathrm{CO}_{2}$ seeps
}

\author{
A.K. Mishra ${ }^{\text {a,b, }}$, R. Santos ${ }^{\text {a }}$, J.M. Hall -Spencer ${ }^{\text {b,c }}$ \\ a Centre for Marine Sciences, University of Algarve, Campus de Gambelas, Faro, 8005-139, Portugal \\ ${ }^{\mathrm{b}}$ School of Biological and Marine Sciences, University of Plymouth, Plymouth, PL48A, UK \\ ${ }^{c}$ Shimoda Marine Research Centre, University of Tsukuba, Shizuoka, 415-0025, Japan
}

\section{A R T I C L E I N F O}

\section{Keywords:}

Bioaccumulation

Bioavailability

Ocean acidification

Posidonia oceanica

Cymodocea nodosa

\begin{abstract}
A B S T R A C T
Seagrasses often occur around shallow marine $\mathrm{CO}_{2}$ seeps, allowing assessment of trace metal accumulation. Here, we measured $\mathrm{Cd}, \mathrm{Cu}, \mathrm{Hg}, \mathrm{Ni}, \mathrm{Pb}$ and $\mathrm{Zn}$ levels at six $\mathrm{CO}_{2}$ seeps and six reference sites in the Mediterranean. Some seep sediments had elevated metal concentrations; an extreme example was Cd which was 43x more concentrated at a seep site than its corresponding reference site. Three seeps had metal levels that were predicted to adversely affect marine biota, namely Vulcano (for $\mathrm{Hg}$ ), Ischia (for $\mathrm{Cu}$ ) and Paleochori (for $\mathrm{Cd}$ and $\mathrm{Ni}$ ). There were higher-than-sediment levels of $\mathrm{Zn}$ and $\mathrm{Ni}$ in Posidonia oceanica and of $\mathrm{Zn}$ in Cymodocea nodosa, particularly in roots. High levels of $\mathrm{Cu}$ were found in Ischia seep sediments, yet seagrass was abundant there, and the plants contained low levels of $\mathrm{Cu}$. Differences in bioavailability and toxicity of trace elements helps explain why seagrasses can be abundant at some $\mathrm{CO}_{2}$ seeps but not at others.
\end{abstract}

\section{Introduction}

Around $30 \%$ of anthropogenic $\mathrm{CO}_{2}$ emissions dissolve into the surface ocean causing the $\mathrm{pH}$ to fall in a process known as 'ocean acidification' (Caldeira and Wickett, 2003). Seawater acidification poses a threat to marine species and ecosystems, so one of the United Nations Sustainable Development Goals 14 is to 'Minimize and address the impacts of ocean acidification' (United Nations, 2015). Rising $\mathrm{CO}_{2}$ levels are expected to reduce seascape complexity, alter trophic interactions (Nogueira et al., 2017; Milazzo et al., 2019) and reduce biodiversity (Sunday et al., 2016) causing impacts on a range of ecosystem services (Lemasson et al., 2017).

Trace elements, as the term suggests, normally occur in very low concentrations. At low levels they are not toxic, and some are essential for cellular process that support life (Avelar et al., 2013). At higher concentration, trace elements such as arsenic (As), copper (Cu), mercury $(\mathrm{Hg})$ and lead $(\mathrm{Pb})$ can be harmful to coastal biota (Stumm Morgan, 1995). Element toxicity depends on the chemical form. Arsenic, for example, is toxic in its metalloid form, $\mathrm{Hg}$ and $\mathrm{Pb}$ are toxic as free ions, and $\mathrm{Cu}$ is toxic when reduced to $\mathrm{Cu}$ (I) (Tchounwou et al., 2014). Ocean acidification is expected to exacerbate the harmful effects of metal pollution in coastal ecosystems (Ivanina and Sokolova, 2015; Lewis et al., 2016) because lower seawater $\mathrm{pH}$ can increase the bioavailability and toxicity of metals both in sediments (Roberts et al., 2013) and in the water column (Millero et al., 2009). Lower pH can release metals to water column that were previously bound to sediment (Atkinson et al., 2007). It can also alter the speciation of elements such as $\mathrm{Cu}, \mathrm{Ni}$ and $\mathrm{Zn}$ resulting in increased toxicity (Lacoue-Labarthe et al., 2009, 2012; Zeng and Chen, 2015). However, levels of toxicity will depend on the rate of metal uptake by marine organisms (Batley et al., 2004). The uptake and availability of $\mathrm{Cd}, \mathrm{Co}, \mathrm{Cu}, \mathrm{Hg}, \mathrm{Ni}, \mathrm{Pb}$ and $\mathrm{Zn}$ increase when seawater $\mathrm{pH}$ falls from 8.1 to 7.8 , which is the change in surface seawater $\mathrm{pH}$ that is underway this century (Byrne et al., 1988; Richards et al., 2011). The seawater free ion concentration of $\mathrm{Cu}$, for example is expected to increase by $115 \%$ (Pascal et al., 2010; Richards et al., 2011) and $\mathrm{Pb}$ by 4.6\% (Millero et al., 2009; Dong et al., 2016).

So far, tests on the risks posed by trace metals in ocean acidification conditions have been carried out in laboratory conditions (Besar et al., 2008; Richir and Gobert, 2013; Bravo et al., 2016), which over simplify the complex behaviour of these metals in the marine environment (Millero et al., 2009). Most submarine volcanic seeps have gradients in $\mathrm{pH}$ and trace elements providing natural conditions to assess their uptake by marine biota (Renzi et al., 2011; Kadar et al., 2012; Vizzini et al., 2013). While relationships between organisms, environmental factors and trace elements have received much attention at deep-sea hydrothermal vents (Kadar et al., 2007; Cravo et al., 2007), those relationships at coastal $\mathrm{CO}_{2}$ seeps are little understood.

Here, we investigate metal levels in sediments and seagrasses at

\footnotetext{
* Corresponding author. School of Biological and Marine Sciences, University of Plymouth, Plymouth, PL48A, UK.

E-mail address: amritkumarmishra@gmail.com (A.K. Mishra).
} 
acidified volcanic seeps as well as at reference sites. We choose seagrasses as they deliver important ecosystem services in coastal habitats (Nordlund et al., 2016). They are also predicted to benefit from rising $\mathrm{CO}_{2}$ levels within their thermal limits (Koch et al., 2013; Brodie et al., 2014). Seagrass habitats provide food and nurseries for fish, turtles and mammals (Whitfield, 2017) and are important carbon sinks (Fourqurean et al., 2012). The seagrasses also sequester contaminants such as excess nutrients (Costanza et al., 2014) and metals (Bonanno and Orlando-Bonaca, 2017) and so are used as bioindicators (Catsiki and Panayotidis, 1993). The plants take in trace elements via their roots, rhizomes or leaves and can translocate them between these tissue compartments (Ralph et al., 2006). This introduces trace elements into the food web via grazing and decomposition (Lewis and Devereux, 2009).

Seagrass can be abundant at some shallow-water $\mathrm{CO}_{2}$ seeps (Hall-Spencer et al., 2008; Russell et al., 2013) but are sparse or absent at other seeps (Vizzini et al., 2010, 2013). Studies have shown upregulation of stress-related antioxidant genes in the seagrass Posidonia oceanica at some $\mathrm{CO}_{2}$ seeps (Lauritano et al., 2015) and work on the expression of genes involved in photosynthesis and growth of another common Mediterranean seagrass, Cymodocea nodosa, did not reveal beneficial effects of high $\mathrm{CO}_{2}$ levels near a seep (Olivé et al., 2017). Under laboratory $\mathrm{CO}_{2}$ enrichment there was significantly increased expression of C. nodosa transcripts associated with photosynthesis (Ruocco et al., 2017). So, even though seagrasses can be common at certain $\mathrm{CO}_{2}$ seeps, toxins may cause stress and stunt their growth.

Laboratory studies have shown that, at elevated $\mathrm{CO}_{2}, \mathrm{Cu}, \mathrm{Pb}$ and $\mathrm{Zn}$ are toxic to the seagrasses Zostera capricorni (Ambo-Rappe et al., 2007) and Halophila ovalis (Ambo-Rappe et al., 2011). Many volcanic seeps around Greece and Italy have elevated levels of metals and are colonised by seagrass (Vizzini et al., 2010; Apostolaki et al., 2014) yet little is known about the accumulation of these metals in these plants. Here, we expand on work by Vizzini et al. (2013) to quantify the concentrations of trace elements in sediments and seagrass at multiple seep sites around the Mediterranean. Our aim was to find out whether levels of trace elements at volcanic seeps correlated with trace element accumulation in seagrass roots, rhizomes and leaves and whether seagrasses are more tolerant of some metals than others.

\section{Methods}

\section{Study sites}

We surveyed six sites in the Mediterranean Sea, all of which had seagrasses (Posidonia oceanica or Cymodocea nodosa) growing on sand in the naturally high salinity and high alkalinity waters of the Mediterranean Sea (Table 1). At each site, a high $\mathrm{CO}_{2}$ station and a reference station was sampled between May-July 2014. The annual temperature range was around $18-22^{\circ} \mathrm{C}$ for all six locations and the $\mathrm{CO}_{2}$ seeps were at $0-10 \mathrm{~m}$ depth with a tidal range of $0.30-0.50 \mathrm{~m}$.

\section{Vulcano, Italy}

We sampled Levante Bay $(38.4 \mathrm{~N}, 15.0 \mathrm{E})$ off Vulcano island (Fig. 1A). The underwater gas emissions are $97-98 \% \mathrm{CO}_{2}$ with $2.2 \%$ hydrogen sulfide $\left(\mathrm{H}_{2} \mathrm{~S}\right)$ at the seep site, decreasing to $<0.005 \% \mathrm{H}_{2} \mathrm{~S}$ towards the north-eastern part of the bay (Capaccioni et al., 2001; Boatta et al., 2013; Milazzo et al., 2014). Cymodocea nodosa was absent near the main vents so we collected it on the periphery of the $\mathrm{CO}_{2}$ seeps at $1 \mathrm{~m}$ depth.

\section{Ischia, Italy}

At the Castello Aragonese, off Ischia $\left(40^{\circ} 43^{\prime} 50.4^{\prime \prime} \mathrm{N} ; 13^{\circ} 57^{\prime} 48.2^{\prime \prime} \mathrm{E}\right)$ $\mathrm{CO}_{2}$ bubbles up in shallow water seeps (Fig. 1A). Here the gas is $90-95 \%$ $\mathrm{CO}_{2}, 3-6 \% \mathrm{~N}_{2}, 0.6-0.8 \% \mathrm{O}_{2}, 0.2-0.8 \% \mathrm{CH}_{4}$ and $0.08-0.1 \%$ air and the
Table 1

Seawater salinity, temperature $(\mathrm{T})$, total alkalinity $\left(\mathrm{A}_{\mathrm{T}}\right), \mathrm{pH}$ and $\mathrm{pCO}_{2}$ values (mean $\pm \mathrm{SE}, \mathrm{n}=5$ ) at six Mediterranean $\mathrm{CO}_{2}$ seeps and reference stations between May-July 2014.

\begin{tabular}{lcccll}
\hline Site & Salinity & $\begin{array}{l}\mathrm{T} \\
\left({ }^{\circ} \mathrm{C}\right)\end{array}$ & $\mathrm{pH}_{\mathrm{TS}}$ & $\begin{array}{l}\mathrm{A}_{\mathrm{T}}(\mu \mathrm{mol} \mathrm{kg} \\
\left.\mathrm{SW}^{-1}\right)\end{array}$ & $p \mathrm{CO}_{2}(\mu \mathrm{atm})$ \\
\hline $\begin{array}{l}\text { Vulcano } \\
\text { Reference }\end{array}$ & 35.8 & 21.6 & $8.15 \pm 0.05$ & 2430.86 & $321 \pm 6.8$ \\
$\begin{array}{l}\mathrm{CO}_{2} \text { seep } \\
\text { Ischia }\end{array}$ & 35.8 & 22.4 & $7.93 \pm 0.08$ & 2424.08 & $594 \pm 15.8$ \\
$\begin{array}{l}\text { Reference } \\
\mathrm{CO}_{2} \text { seep }\end{array}$ & 35.6 & 17.7 & $8.11 \pm 0.06$ & 2587.92 & $408 \pm 2.3$ \\
$\begin{array}{l}\text { Panarea } \\
\text { Reference }\end{array}$ & 35.7 & 17.8 & $7.68 \pm 0.05$ & 2581.34 & $1233 \pm 10.2$ \\
$\begin{array}{l}\text { CO } \\
\text { seep }\end{array}$ & 36.0 & 20.5 & $8.17 \pm 0.05$ & 2498.89 & $356 \pm 4.6$ \\
$\begin{array}{l}\text { Adamas } \\
\text { Reference }\end{array}$ & 36.7 & 22.6 & $8.18 \pm 0.03$ & 2706.84 & $340 \pm 1.6$ \\
$\begin{array}{l}\mathrm{CO}_{2} \text { seep } \\
\text { Paleochori }\end{array}$ & 36.7 & 23.5 & $7.48 \pm 0.04$ & 2696.15 & $2107 \pm 1.8$ \\
$\begin{array}{l}\text { Reference } \\
\mathrm{CO}_{2} \text { seep }\end{array}$ & 36.0 & 22.6 & $8.16 \pm 0.01$ & 2702.84 & $342 \pm 1.1$ \\
$\begin{array}{l}\text { Methana } \\
\text { Reference }\end{array}$ & 36.0 & 22.8 & $7.87 \pm 0.01$ & 2698.85 & $883 \pm 3.0$ \\
$\mathrm{CO}_{2}$ seep & 36.8 & 22.8 & $8.17 \pm 0.01$ & 2706.84 & $337 \pm 6.9$ \\
\hline
\end{tabular}

seeps lack $\mathrm{H}_{2} \mathrm{~S}$ (Tedesco, 1996). Abundant Posidonia oceanica meadows were sampled at $0.5 \mathrm{~m}$ depth from the seep area and from a reference site (Fig. 2a).

\section{Panarea, Italy}

Panarea island $\left(38^{\circ} 38^{\prime} 12.2^{\prime \prime} \mathrm{N} ; 15^{\circ} 06^{\prime} 42.5^{\prime \prime} \mathrm{E}\right)$ is part of the Aeolian Archipelago in the Southern Tyrrhenian Sea (Fig. 1A). On the main island and on the surrounding seafloor, tectonic faults have many gas seeps (Gabianelli et al., 1990; Voltattorni et al., 2009). The underwater gas emissions around these seeps are $92-95 \% \mathrm{CO}_{2}, 2.99-6.23 \% \mathrm{~N}_{2}$, $0.69-1.2 \% \mathrm{O}_{2}$ and $0.65-3 \% \mathrm{H}_{2} \mathrm{~S}$ (Caramanna et al., 2010). Here $P$. oceanica was sampled at $5 \mathrm{~m}$ depth.

\section{Milos Islands, Greece}

Adamas thermal springs $(36.70 \mathrm{~N}, 24.46 \mathrm{E})$ and Paleochori Bay $(36.67 \mathrm{~N}, 24.51 \mathrm{E})$ are situated on southwest and southeast part of Milos island respectively (Fig. 1B). Milos island is part of an extensive submarine venting, from the intertidal to depths of more than $100 \mathrm{~m}$ (Dando et al., 1999). The underwater gas seeps at Adamas and Paleochori are located $<1-4 \mathrm{~m}$ depth. The released gases are mainly composed of 92.5\% $\mathrm{CO}_{2}$ with some $\mathrm{CH}_{4}$ and $\mathrm{H}_{2}$ (Bayraktarov et al., 2013). The underwater gas seeps at Adamas thermal station and Paleochori Bay where Cymodocea nodosa meadows were sampled are located at $2 \mathrm{~m}$ and $4 \mathrm{~m}$ depth respectively (Fig. 2b).

\section{Methana, Greece}

The Methana peninsula $(37.638428 \mathrm{~N} ; 23.359730 \mathrm{E})$ is the westernmost volcanic system of the northern Aegean Volcanic Arc (Fig. 1B), derived from the subduction of the African tectonic plate beneath the Eurasian plate. We sampled the area described by Baggini et al. (2014) near Agios Nikolaos village on the NE part of the peninsula. The gases were $90 \% \mathrm{CO}_{2}$, with small amounts of nitrogen, carbon monoxide and methane (D'Alessandro et al., 2008). Here we sampled Posidonia oceanica meadows at $8-10 \mathrm{~m}$ depth.

\section{Water sampling}

Water samples $(\mathrm{n}=5)$ were collected at each $\mathrm{CO}_{2}$ seep and reference station of all six sites in $100 \mathrm{ml}$ Winkler bottles and were fixed with $20 \mu \mathrm{l}$ mercuric chloride in the field, stored in dark cool-boxes and transported 


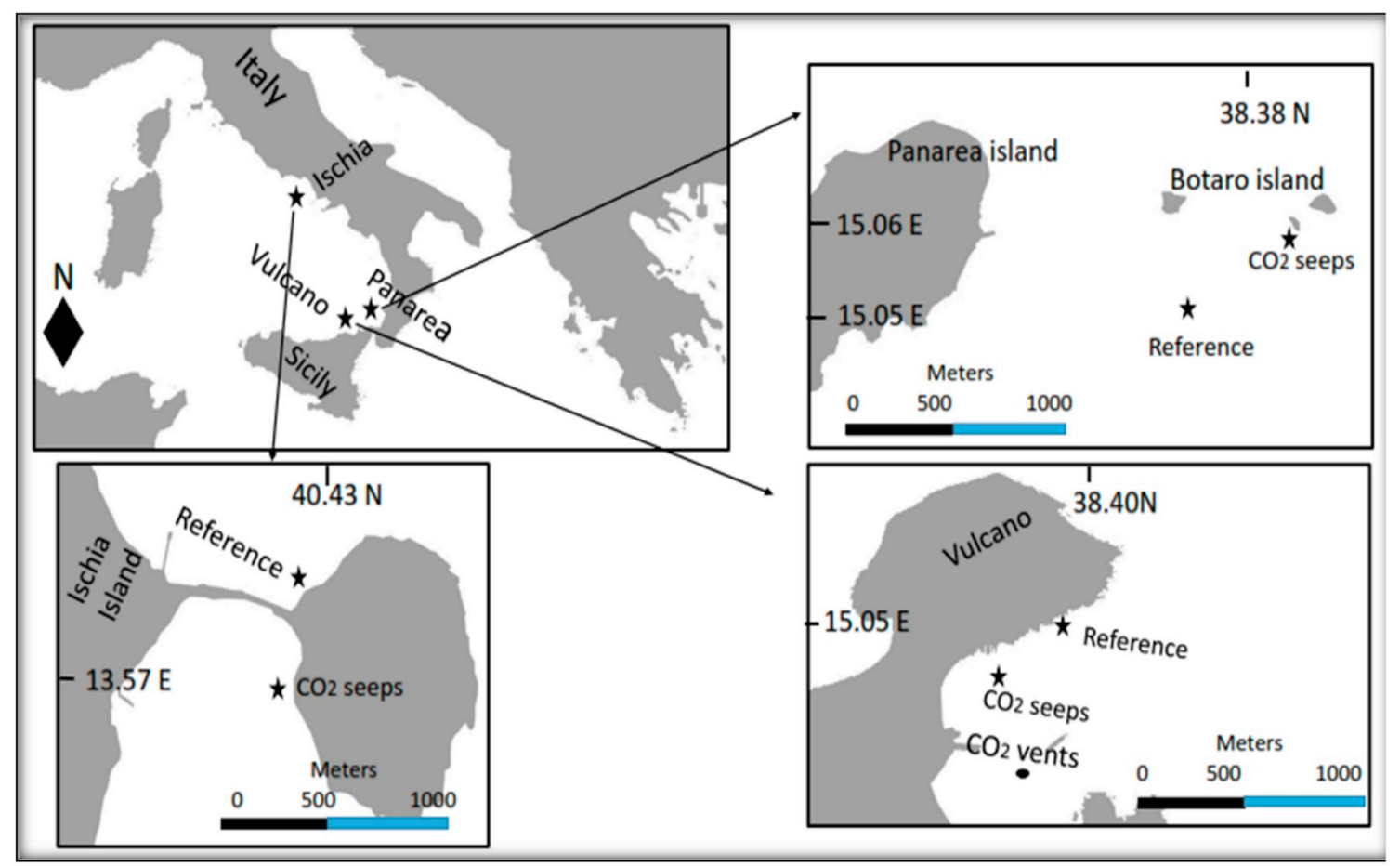

a

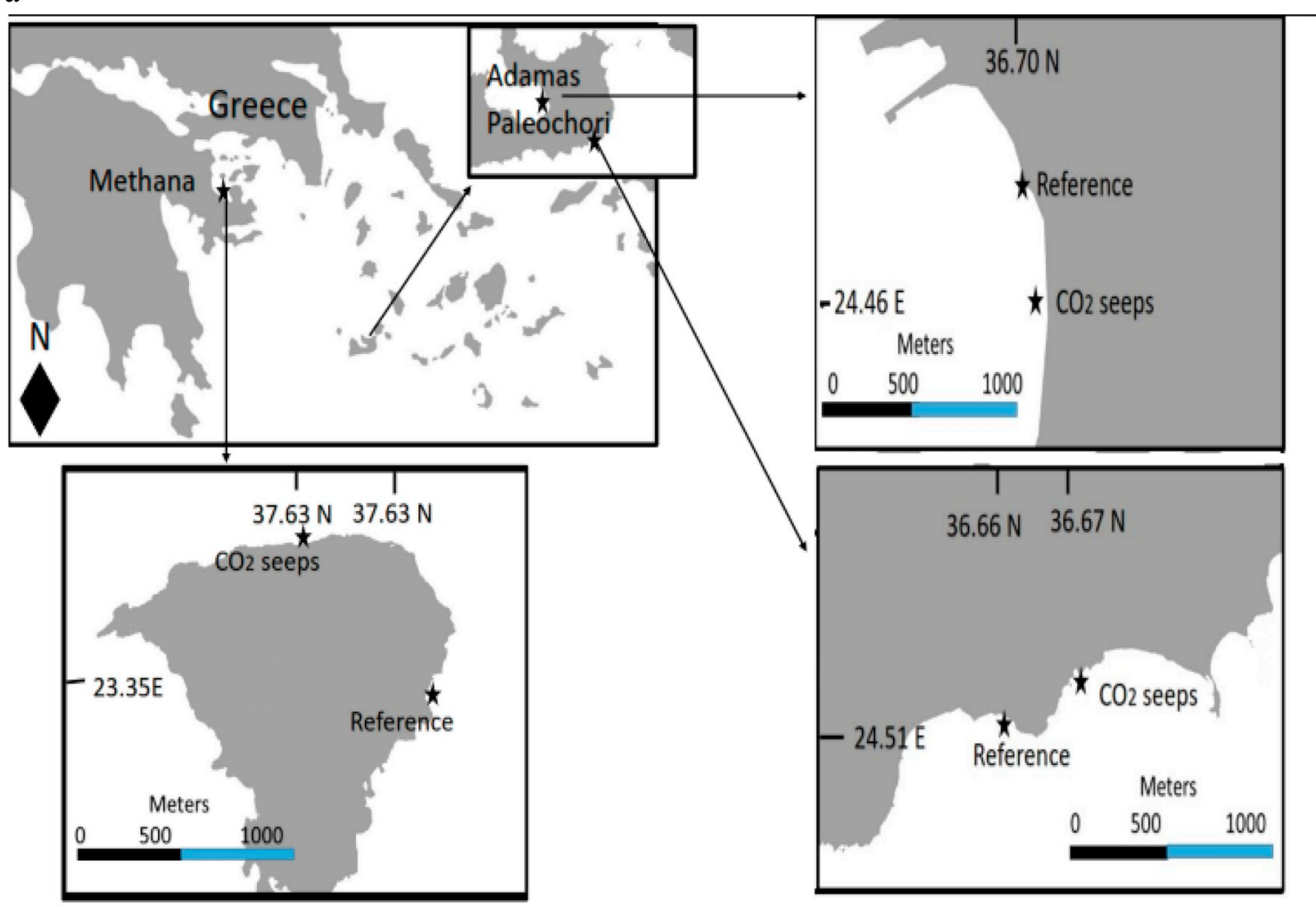

b

Fig. 1. Study sites in Italy a) and b) Greece, showing reference and $\mathrm{CO}_{2}$ seep sites, which were all sampled between May to July 2014 .

to the laboratory for total alkalinity $\left(\mathrm{A}_{\mathrm{T}}\right)$ analysis. $\mathrm{The} \mathrm{pH}_{\mathrm{TS}}$ (using $\mathrm{pH}$ meter, Titrino Methron, Thermo Scientific) and temperature of the water samples were measured in the field immediately after collection and then measured in the laboratory again during the $\mathrm{A}_{\mathrm{T}}$ analysis. In the laboratory $80 \mathrm{ml}$ water samples were analysed for $\mathrm{A}_{\mathrm{T}}$ using a Lab Titrino analyser following methods given by Dickson et al. (2007). Sterilized sea water was used as reference materials (CRM Batch 129, accuracy-98.7\%
Dickson, 2013) for $A_{T}$ analysis. Temperature, $\mathrm{pH}_{T S}$ and $\mathrm{A}_{T}$ data were used to calculate $p \mathrm{CO}_{2}$ using $\mathrm{CO}_{2} \mathrm{SYS}$ program following methods given by Pierrot et al. (2006). Dissociation constants $\left(\mathrm{K}_{1}\right.$ and $\left.\mathrm{K}_{2}\right)$ developed by Mehrbach et al. (1973) and refitted by Dickson and Millero, 1987 and dissociated constant for boric acid $\left(\mathrm{K}_{\mathrm{B}}\right)$ developed by Dickson et al. (2007) was used in $p \mathrm{CO}_{2}$ calculation. 


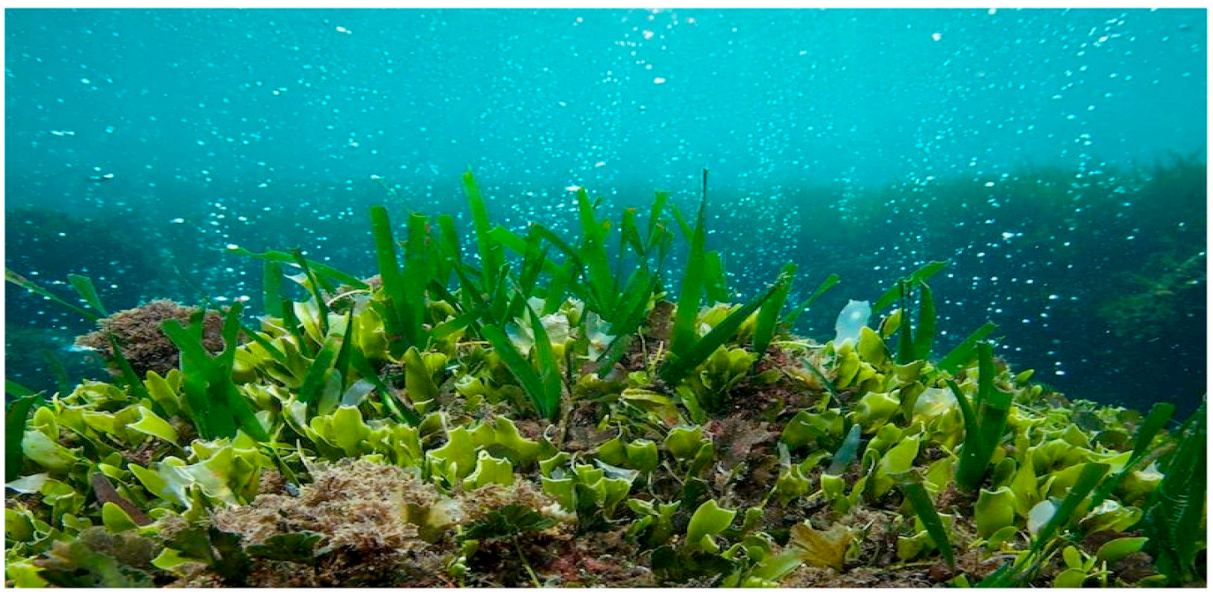

a

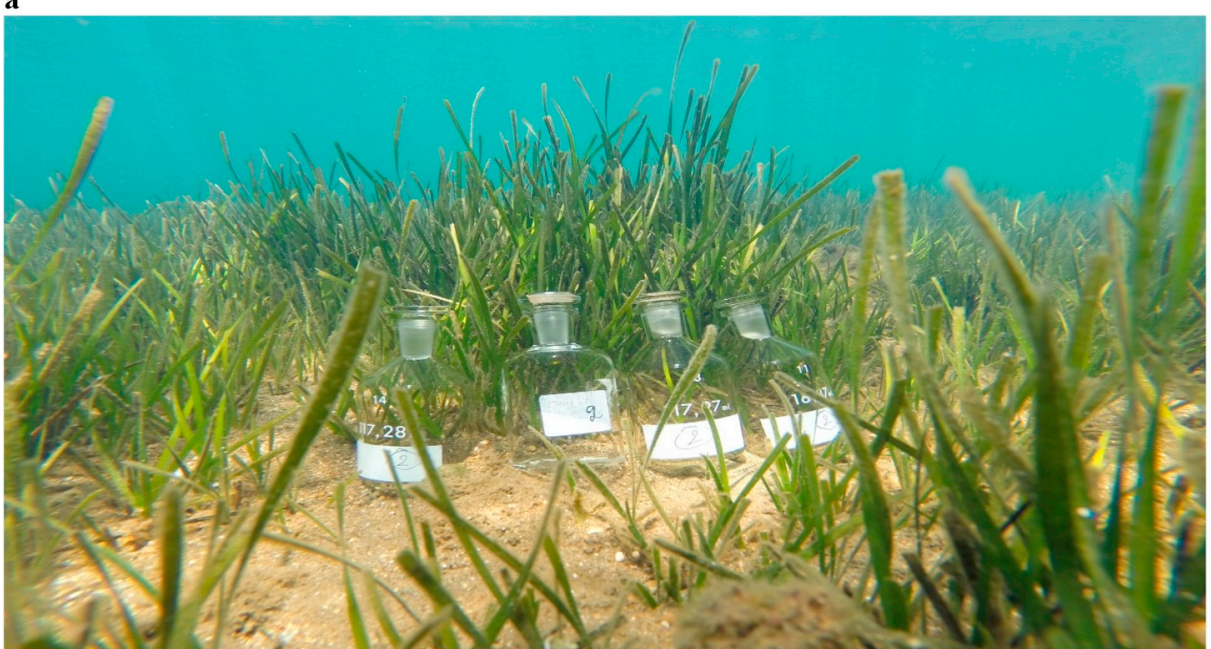

b

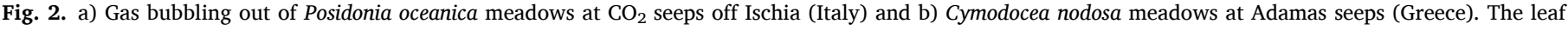

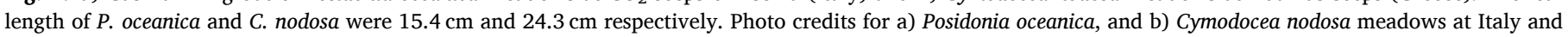
Greece: Jason Hall Spencer, University of Plymouth, UK and Thanos Dailianis of Hellenic Centre for Marine Research, Greece respectively

\section{Sediment \& seagrass sampling}

Sediment samples $(\mathrm{n}=5)$ were collected $1 \mathrm{~m}$ apart from six $\mathrm{CO}_{2}$ seeps and six reference stations by SCUBA diving. A $10-\mathrm{cm}$ long and $2 \mathrm{~cm}$ diameter syringe with the tip cut off to was used to suck up the upper $5 \mathrm{~cm}$ of sand. The sediment samples were stored in plastic bags in dark boxes and transferred to the laboratory. They were then dried at $40^{\circ} \mathrm{C}$ until a constant weight was achieved and then analysed for the grain size following dry sieving at Half Phi intervals (Blott and Pye, 2001). After grain size analysis the fine and very fine of sediment fraction $(<180$ $63 \mu \mathrm{m}$ ) were collected and stored in plastic bottles for trace metal analysis.

Samples ( $\mathrm{n}=5$, whole plants) of Cymodocea nodosa (from Vulcano, Adamas and Paleochori islands) and Posidonia oceanica (from Ischia, Panarea and Methana) were collected by SCUBA diving at each station. The plants were rinsed well to remove sediment, scraped to remove leaf epiphytes and leaf scales were removed from rhizomes ( $P$. oceanica) by hand and with soft tooth-brush and then washed with distilled water, air-dried and stored in polybags until analyses. Seagrass leaves, roots and rhizomes were oven dried at $40{ }^{\circ} \mathrm{C}$ and powdered in a mortar and stored till further analysis.

\section{Analytical methods}

Total trace elements (Cd, $\mathrm{Cu}, \mathrm{Hg}, \mathrm{Ni}, \mathrm{Pb}$ and $\mathrm{Zn}$ ) concentrations were determined using Aqua Regia Soluble Total method (Modified by Laboratory of the Government Chemist (LGC) UK from ISO11466). Dried sediment $(0.25 \mathrm{~g})$ was put into digestion tubes (Tecator type). Cold and concentrated acids in the order: $4.5 \mathrm{ml}$ Hydrochloric acid ( $\mathrm{HCl}): 1.5 \mathrm{~mL}$ Nitric acid $\left(\mathrm{HNO}_{3}\right)$ was added to the tubes. The digestion tubes were left to pre-digest, for $1 \mathrm{~h}$ then heated for $2 \mathrm{~h}$ at $95-100^{\circ} \mathrm{C}$. After cooling, the digest was filtered quantitatively into a volumetric flask and diluted using $2 \% \mathrm{HNO}_{3}$ (25 ml volume).

For dried seagrass (leaves, rhizomes and roots), $0.25 \mathrm{~g}$ of sample was added to $6 \mathrm{~mL}$ of $\mathrm{HNO}_{3}$ following the same procedure as metals and the volume was made up to $25 \mathrm{~mL}$. Similarly, blanks and standards (LGC Reference Materials, UK, recovery-95\%) used for sediments (LCG6156) and plants (LGC7162) were prepared using the same method. Analysis of $\mathrm{Cd}, \mathrm{Co}, \mathrm{Cu}, \mathrm{Hg}, \mathrm{Pb}$ and $\mathrm{Zn}$ was performed using an ICP-MS (Thermo Scientific, iCAP 7000 Series) and an ICP-AES (Thermo Scientific, X Series-2) in triplicate with analytical detection precision of $99.5 \%$.

All acids were analytical grade. Normal precautions for metal analysis were observed throughout the analytical procedures. HCL (37\%w/ w) and $\mathrm{HNO}_{3}(69 \% \mathrm{w} / \mathrm{w})$ were Ultrapure type (Ultrapure, Fischer Chemicals, USA). All glassware was soaked overnight in $10 \% \mathrm{HNO}_{3}$ and washed with distilled water and oven dried before use.

\section{Data analysis}

To assess the sediment quality of all six locations we used Sediment 
Quality Guidelines Quotient (SQG-Q, Long and MacDonald, 1998). Among the environmental quality indices in the literature, this was chosen for its simplicity, comparability and robustness as reported by Caeiro et al. (2005). The SQG-Q consists of two values: a threshold effects level (TEL) and a probable effect level (PEL) (MacDonald et al., 1996). TEL and PEL, represent concentrations below which adverse biological effects occur rarely and frequently.

The SQG-Q was calculated as follows

SQG-Q $=\left(\Sigma^{\mathrm{n}}{ }_{\mathrm{i}=1}\right.$ PEL-Q $\left.\mathrm{i}\right) / \mathrm{n}$

Where PEL- $\mathrm{Q}_{\mathrm{i}}=$ contaminant/PEL. The PEL-Qi represents the probable effect level quotient (PEL-Q) of the $\mathrm{i}$ contaminant and $\mathrm{n}$ represents the total number of contaminants (trace metals). Using the SQG-Q index, the sediments were divided into three categories as established by MacDonald et al. (2000). SGQ-Q $\leq 0.1$ - low potential for adverse biological effects; $0.1<$ SQG-Q $<1$ - moderate potential for adverse biological effects; SQG-Q $\geq 1$ - high potential for adverse biological effects.

To assess bio-accumulation of elements, we calculated the Bio Sediment Accumulation Factor (BSAF), which is defined as the ratio between metal concentration in the organism and that in the sediment (Lau et al., 1998; Szefer et al., 1999), given by:

$\mathrm{BSAF}=\mathrm{Mp} / \mathrm{Ms}$

Where $\mathrm{Mp}$ is the concentration of the element in the seagrass and $\mathrm{Ms}$ is the concentration of the element in the sediment (Fergusson 1990). BSAF is a key factor in expressing the efficiency of seagrass species to absorb elements from sediments and concentrate specific element in its roots, rhizomes or leaves. Higher BSAF values $(>1)$ indicate a greater capability of accumulation (EPA, 2007).

\section{Statistics}

A three-way ANOVA was used to test for significant differences in trace element concentration among locations (Ischia, Panarea and Methana for $P$. oceanica and Adamas, Paleochori and Vulcano for C. nodosa), compartments (sediments and leaves, rhizomes, roots) and stations $\left(\mathrm{CO}_{2}\right.$ seeps, Reference). All data were first checked for normality and homogeneity of variances. When variances were not homogenous, data were $\ln (\mathrm{x}+1)$ transformed. When there were significant effects, the Holm-Sidak test was performed for a posteriori comparison among factor levels. Pearson's correlation co-efficient was applied to identify correlations between trace element concentration in sediment and seagrass compartments, after testing for normality of distribution on raw or $\log$ transformed data. When normality was not achieved, nonparametric Spearman's rank correlation coefficient was applied. All statistical tests were conducted with a significance level of $\alpha=0.05$ and data were reported as mean \pm standard error (SE).

\section{Results}

Dissolved $\mathrm{CO}_{2}$ concentrations were highest (and $\mathrm{pH}$ lowest) at each of the seeps; reference sites had normal $\mathrm{CO}_{2}$ and $\mathrm{pH}$ levels. Salinity, temperature and total alkalinity were not affected by the seeps (Table 1).

Grain size analysis showed that $99 \%$ of the sediment particles sampled at all locations were sand. Most sediment trace element levels were significantly higher in the sediments of seeps than at reference stations, except Ischia (Figs. 3 and 4). Large differences were found for $\mathrm{Ni}$ (5.3-fold) and Zn (2.39-fold) at Panarea, Cd (42.6-fold) at Paleochori and $\mathrm{Cu}$ (8.9- fold) at Adamas seep sediments, compared to reference stations. Mercury was only observed at Italian $\mathrm{CO}_{2}$ seeps, with 1.4-fold higher levels in the seep sediments at Vulcano than at Ischia and Panarea. Zinc sediment concentrations were similar at all locations but were 1.7-fold lower at Methana than at Ischia. However, Zn levels at the seeps of Panarea were 2.3-fold higher than at reference sites. The environmental quality of seep sediments for trace elements derived from the
Sediment Quality Guidelines Quotient was mainly 'Moderate', although it was in the 'Low' to 'Moderate' range for reference stations. 'Adverse' biological effects were considered likely due to high levels of $\mathrm{Hg}$ at Vulcano, $\mathrm{Cu}$ at Ischia plus $\mathrm{Ni}$ and $\mathrm{Cd}$ at Paleochori (Table 2).

We were especially interested in results from Ischia as $P$. oceanica was abundant within the main $\mathrm{CO}_{2}$ seep area (Fig. 2a). The sediment at this seep has the highest $\mathrm{Cu}$ (32-fold), $\mathrm{Zn}$ (2-fold) and $\mathrm{Pb}$ (1.5-fold) concentrations than other two seep locations sampled for $P$. oceanica, but the seagrass tissues had low levels of these metals (Fig. 3). On the other hand, $P$. oceanica at the Ischia seeps had higher concentrations of Cd (1.9-fold), Hg (1.2-fold), Ni (3-fold) and Zn (4-fold) than the sediment (Fig. 3). The concentrations of $\mathrm{Ni}$ at Paleochori, $\mathrm{Pb}$ at Vulcano and $\mathrm{Zn}$ at Adamas seeps were 18-fold, 4-fold and 3-fold higher in the sediment than in C. nodosa (Fig. 4). Trace element levels were generally significantly higher in the roots than rhizomes and leaves of $P$. oceanica and C. nodos $a$ at all seep locations (Figs. 3 and 4). Exceptions were Cd (8fold) concentrations within the rhizomes, $\mathrm{Zn}$ (42-fold) and $\mathrm{Cu}$ (5-fold) within the leaves of $P$. oceanica and $\mathrm{Cd}$ (6-fold), $\mathrm{Pb}$ (4-fold) and $\mathrm{Hg}$ (3fold) within leaves of $C$. nodosa (Figs. 3 and 4).

Significant differences between the three sampling sites in the levels of trace elements in sediment and tissues were observed for $P$. oceanica (Table 3). Element concentrations measured in sediments and $P$. oceanica compartments differed significantly except for $\mathrm{Cu}$ (sedimentleaves) and $\mathrm{Zn}$ (sediment-roots), whereas within $P$. oceanica compartments all elements, except $\mathrm{Pb}$ (roots-leaves) has significant differences at all three sites. The accumulation of elements in $P$. oceanica plant parts did not show consistent common patterns for the three sampling sites. $\mathrm{Hg}$ and $\mathrm{Cu}$ were generally higher in roots and leaves than in rhizomes in all reference and seep sites. Zn was much higher in the leaves than in other plant parts at Ischia and Panarea. On the other hand, Cd was higher in the rhizomes of $P$. oceanica in reference and seep sites of Ischia and Panarea (Fig. 3).

Significant variation was observed in trace element levels for C. nodosa between the three sites, except for $\mathrm{Cu}$ at Adamas vs Paleochori, $\mathrm{Ni}$ at Vulcano vs Adamas and $\mathrm{Pb}$ at Vulcano vs Paleochori (Table 4). Element levels measured in sediment and in C. nodosa compartments differed significantly, except for $\mathrm{Cu}$ (sediment vs rhizomes). The accumulation of elements in C. nodosa plant parts did not show highly

Table 2

Sediment Quality Guidelines-quotient (SQG-Q) of sediment calculated with Probable Effects Level for Reference and $\mathrm{CO}_{2}$ seep sites in Greece and Italy. SQG$\mathrm{Q}<0.1$ (low effect), $<0.1$ SQG-Q $>1$ (moderate effect), SQG-Q $>1$ (adverse biological effects). Numbers in bold indicate possible adverse effects of trace elements.

\begin{tabular}{|c|c|c|c|c|c|}
\hline \multirow[t]{2}{*}{ Location } & \multirow[t]{2}{*}{ Element } & SQG-Q & \multirow{2}{*}{$\mathrm{CO}_{2}$ seeps } & \multirow{2}{*}{$\frac{\text { Effects }}{\text { Reference }}$} & \multirow[t]{2}{*}{$\mathrm{CO}_{2}$ seeps } \\
\hline & & Reference & & & \\
\hline \multirow[t]{4}{*}{ Vulcano } & $\mathrm{Cu}$ & 0.08 & 0.33 & Low & Moderate \\
\hline & $\mathrm{Hg}$ & 0.32 & 1.18 & Moderate & Adverse \\
\hline & $\mathrm{Ni}$ & 0.13 & 0.21 & Moderate & Moderate \\
\hline & $\mathrm{Zn}$ & 0.09 & 0.13 & Low & Moderate \\
\hline \multirow[t]{4}{*}{ Ischia } & $\mathrm{Cu}$ & 0.93 & 1.06 & Moderate & Adverse \\
\hline & $\mathrm{Hg}$ & 0.64 & 0.86 & Moderate & Moderate \\
\hline & $\mathrm{Pb}$ & 0.11 & 0.13 & Moderate & Moderate \\
\hline & $\mathrm{Zn}$ & 0.12 & 0.10 & Moderate & Moderate \\
\hline \multirow[t]{6}{*}{ Panarea } & $\mathrm{Cd}$ & 0.10 & 0.16 & Low & Moderate \\
\hline & $\mathrm{Cu}$ & 0.06 & 0.11 & Low & Moderate \\
\hline & $\mathrm{Hg}$ & 0.79 & 0.84 & Moderate & Moderate \\
\hline & $\mathrm{Ni}$ & 0.03 & 0.18 & Low & Moderate \\
\hline & $\mathrm{Pb}$ & 0.09 & 0.57 & Low & Moderate \\
\hline & $\mathrm{Zn}$ & 0.05 & 0.12 & Low & Moderate \\
\hline \multirow[t]{2}{*}{ Adamas } & $\mathrm{Cd}$ & 0.21 & 0.21 & Moderate & Moderate \\
\hline & $\mathrm{Ni}$ & 0.31 & 0.41 & Moderate & Moderate \\
\hline \multirow[t]{2}{*}{ Paleochori } & $\mathrm{Cd}$ & 0.04 & 1.84 & Low & Adverse \\
\hline & $\mathrm{Ni}$ & 0.71 & 1.01 & Moderate & Adverse \\
\hline \multirow[t]{2}{*}{ Methana } & $\mathrm{Ni}$ & 0.11 & 0.16 & Moderate & Moderate \\
\hline & $\mathrm{Pb}$ & 0.05 & 0.42 & Low & Moderate \\
\hline
\end{tabular}



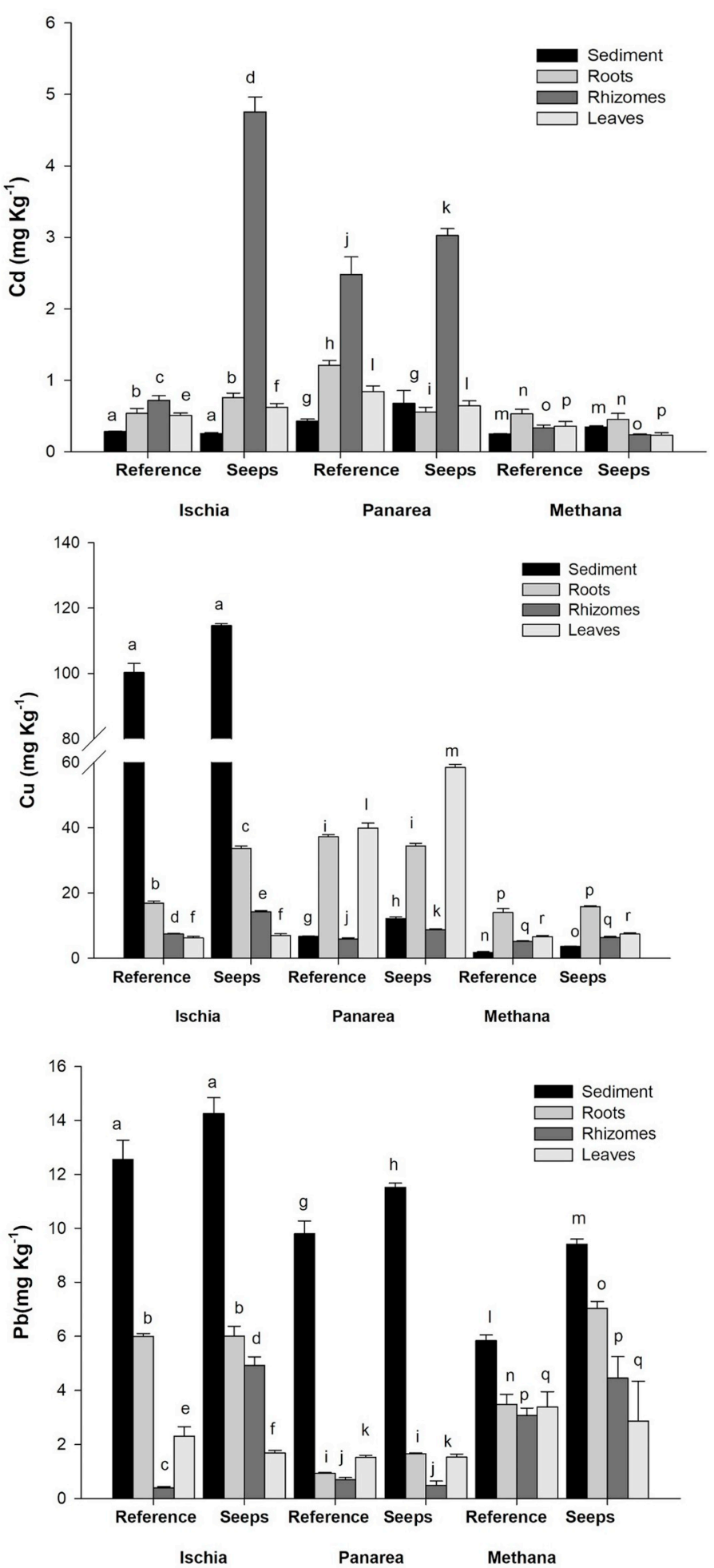
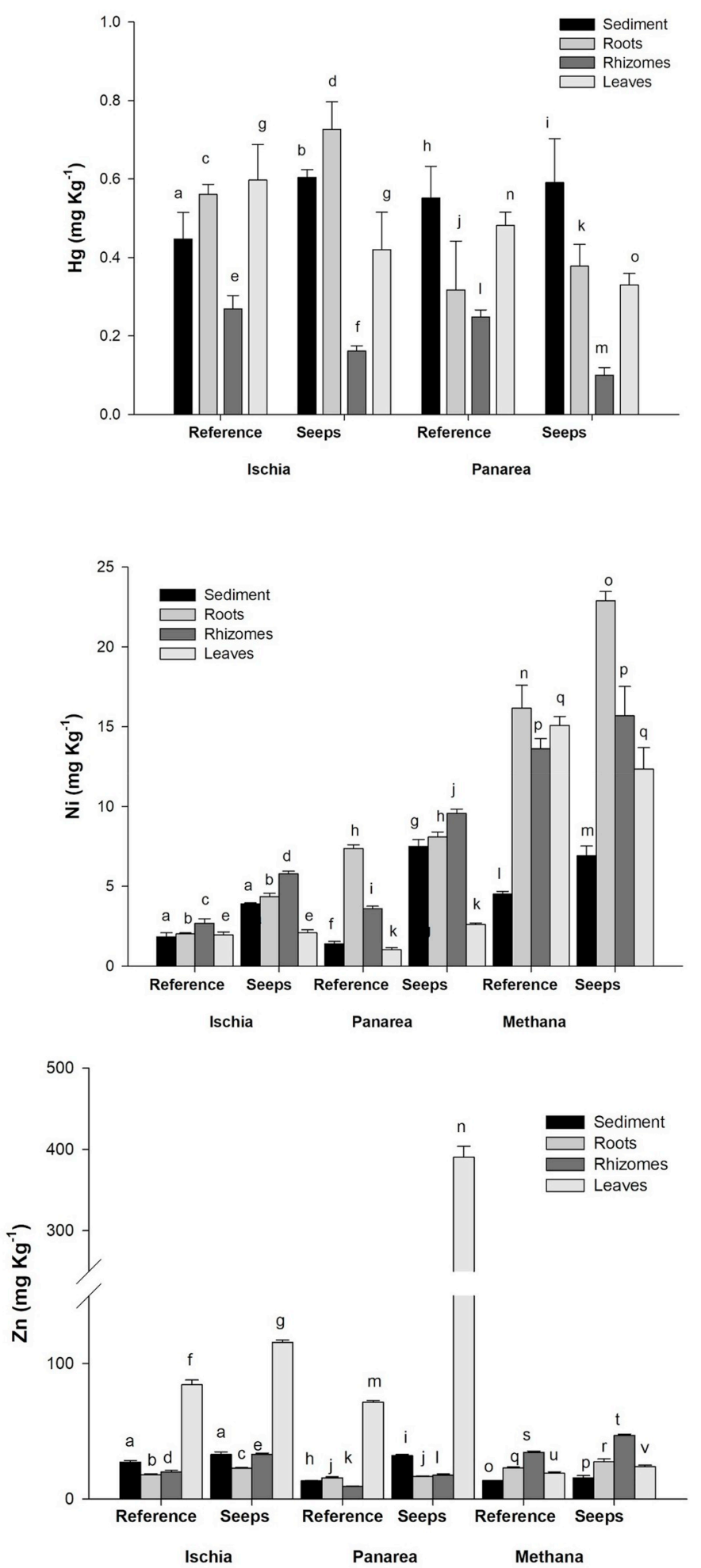

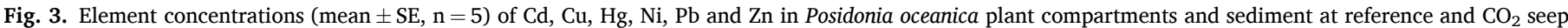
sites off Italy and Greece. Different letters indicate significant differences between reference and $\mathrm{CO}_{2}$ seeps site at each location.

consistent common patterns as in P. oceanica (Fig. 4). However, Cu was always much higher in roots than other plant parts and $\mathrm{Hg}$ was higher in both roots and leaves than in rhizomes.

Correlation between trace element content in sediments and those recorded in $P$. oceanica roots and rhizomes were significant and positive for $\mathrm{Zn}$ and $\mathrm{Ni}$ in rhizomes at Ischia and Panarea seeps respectively, whereas in roots $\mathrm{Cd}$ was observed with positive correlation only at
Panarea seeps (Table 5). Correlations of trace element content in sediment and those observed in roots and rhizomes of $C$. nodosa were significant and negative for $\mathrm{Pb}$ in both roots and rhizomes and for $\mathrm{Zn}$ only in rhizomes at Vulcano seeps (Table 5).

The Bio-Sediment Accumulation Factor indicated that in $P$. oceanica there was high root accumulation of $\mathrm{Cd}$ at all three sites and of $\mathrm{Cu}$ at Panarea and Methana. In C. nodosa, there was high accumulation of $\mathrm{Cu}$ 

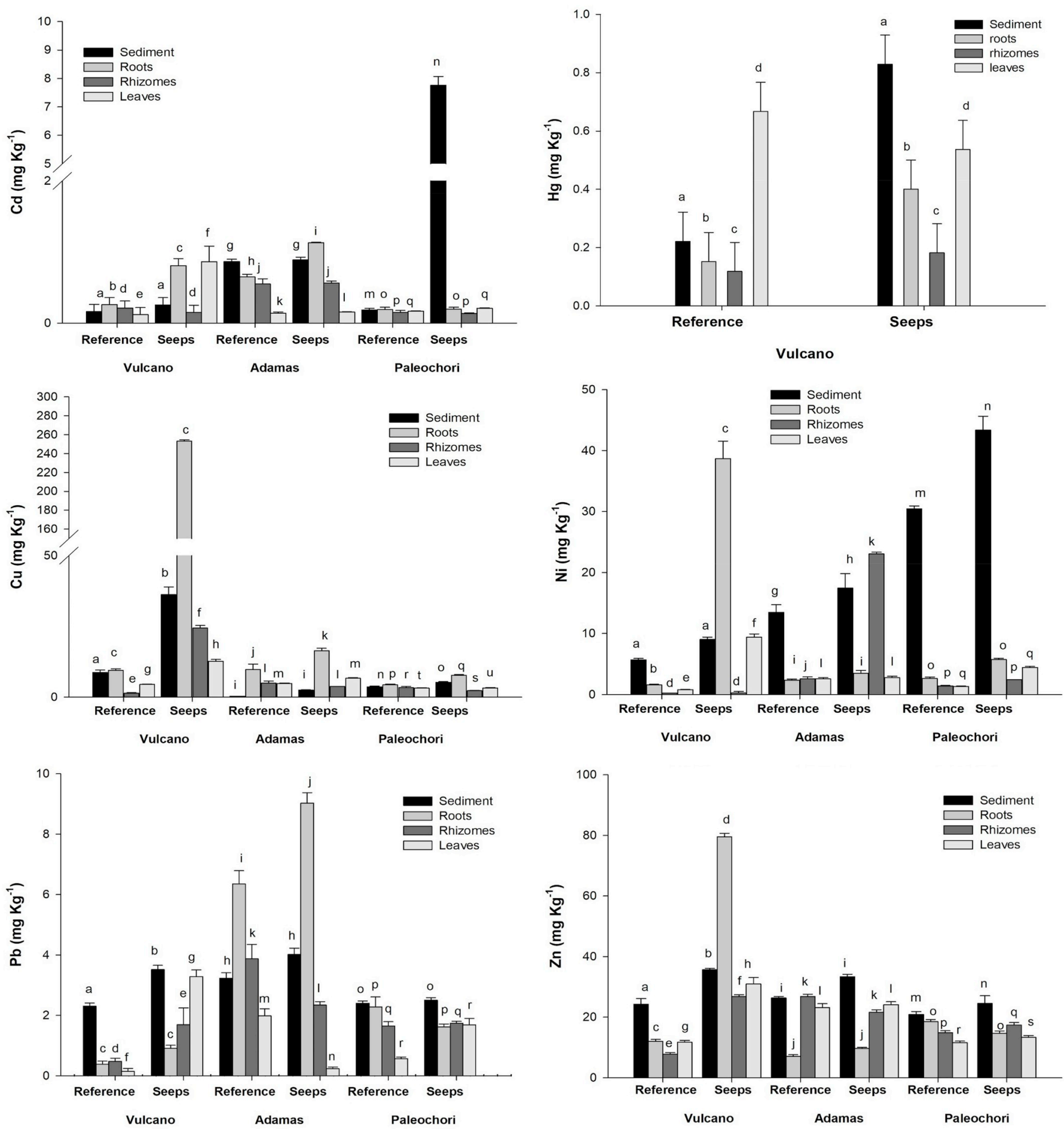

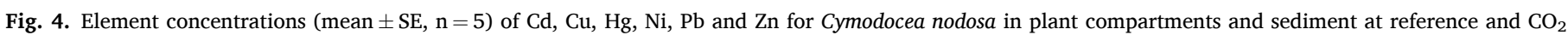
seeps off Italy and Greece. Different letters indicate significant differences between reference and $\mathrm{CO}_{2}$ seep sites for each location.

in the roots at all three sites (Table 6).

\section{Discussion}

Shallow water $\mathrm{CO}_{2}$ seeps have been used as natural analogues for future coastal ecosystems as they can have areas of seabed where entire communities of marine organisms are exposed to the shifts in carbonate chemistry that are expected due to continued anthropogenic $\mathrm{CO}_{2}$ emissions (Hall-Spencer et al., 2008; Enochs et al., 2015; Connell et al., 2017). At such seeps, there are often elevated levels of trace elements and $\mathrm{H}_{2} \mathrm{~S}$, so care is needed when using them to assess the effects of ocean acidification (Barry et al., 2010; Vizzini et al., 2010). This is done by mapping areas affected by volcanic fluid toxics and avoiding those areas when assessing the effects of increased $p \mathrm{CO}_{2}$ in seawater (Boatta et al., 2013; Agostini et al., 2018). The six $\mathrm{CO}_{2}$ seeps that we surveyed showed sediments were enriched with $\mathrm{Cd}, \mathrm{Cu}, \mathrm{Hg}, \mathrm{Ni}, \mathrm{Pb}$ and $\mathrm{Zn}$. This was expected since hydrothermal seep sediments often have high levels of metals (Aiuppa et al., 2000; Sternbeck and Östlund, 2001) due to continuous input from the subsea floor into the sediments (Dando et al., 1999). The calculated Sediment Quality Guidelines Quotient (Long and 
Table 3

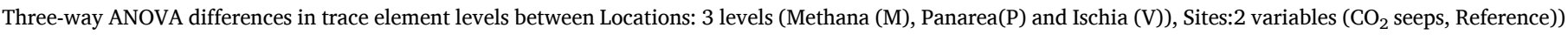

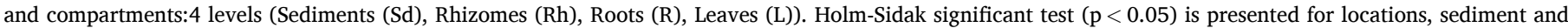
$P$. oceanica compartments. Numbers in bold indicate differences that were not significant.

\begin{tabular}{|c|c|c|c|c|c|c|c|c|c|c|c|}
\hline \multirow[t]{3}{*}{ Element } & \multirow[t]{3}{*}{ Variation } & \multirow[t]{3}{*}{$\mathrm{p}$ value } & \multicolumn{6}{|c|}{ Holm-Sidak p values } & & & \multirow[b]{3}{*}{$\mathrm{R}$ vs $\mathrm{L}$} \\
\hline & & & \multicolumn{3}{|l|}{ Location } & \multicolumn{3}{|c|}{ Sediment vs Compartment } & \multicolumn{2}{|c|}{ Compartments } & \\
\hline & & & M vs $P$ & M vs V & V vs $P$ & Sd vs R & Sd vs Rh & Sd vs L & $\mathrm{R}$ vs $\mathrm{Rh}$ & Rh vs L & \\
\hline \multirow[t]{3}{*}{ Cd } & Location & $<0.001$ & $<0.001$ & $<0.001$ & $<0.001$ & & & & & & \\
\hline & Station & $<0.001$ & & & & & & & & & \\
\hline & Compt. & $<0.001$ & & & & $<0.001$ & $<0.001$ & $<0.001$ & $<0.001$ & $<0.001$ & $<0.001$ \\
\hline \multirow[t]{3}{*}{$\mathrm{Cu}$} & Location & $<0.001$ & $<0.001$ & $<0.001$ & $<0.001$ & & & & & & \\
\hline & Station & $<0.001$ & & & & & & & & & \\
\hline & Compt. & $<0.001$ & & & & $<0.001$ & $<0.001$ & 0.314 & $<0.001$ & $<0.001$ & $<0.001$ \\
\hline \multirow[t]{3}{*}{$\mathrm{Ni}$} & Location & $<0.001$ & $<0.001$ & $<0.001$ & $<0.001$ & & & & & & \\
\hline & Station & $<0.001$ & & & & & & & & & \\
\hline & Compt. & $<0.001$ & & & & $<0.001$ & $<0.001$ & $<0.001$ & $<0.001$ & $<0.001$ & $<0.001$ \\
\hline \multirow[t]{3}{*}{$\mathrm{Pb}$} & Location & $<0.001$ & $<0.001$ & $<0.001$ & $<0.001$ & & & & & & \\
\hline & Station & $<0.001$ & & & & & & & & & \\
\hline & Compt. & $<0.001$ & & & & $<0.001$ & $<0.001$ & $<0.001$ & $<0.001$ & $<0.001$ & 0.652 \\
\hline \multirow[t]{3}{*}{$\mathrm{Zn}$} & Location & $<0.001$ & $<0.001$ & $<0.001$ & $<0.001$ & & & & & & \\
\hline & Station & $<0.001$ & & & & & & & & & \\
\hline & Compt. & $<0.001$ & & & & 0.222 & $<0.001$ & $<0.001$ & $<0.001$ & $<0.001$ & $<0.001$ \\
\hline
\end{tabular}

Table 4

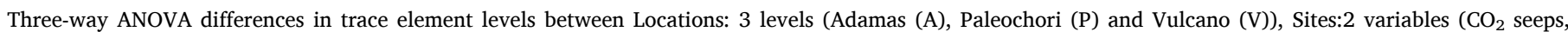

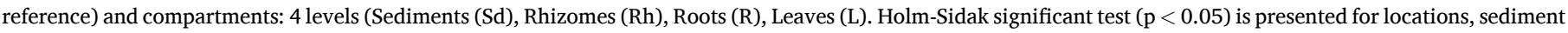
and $C$. nodosa compartments. Numbers (in bold) indicate differences that were not significant.

\begin{tabular}{|c|c|c|c|c|c|c|c|c|c|c|c|}
\hline \multirow[t]{3}{*}{ Element } & \multirow[t]{3}{*}{ Variation } & \multirow[t]{3}{*}{$\mathrm{p}$ value } & \multicolumn{6}{|c|}{ Holm-Sidak p values } & & & \multirow[b]{3}{*}{$R$ vs $L$} \\
\hline & & & \multicolumn{3}{|c|}{ Location } & \multicolumn{3}{|c|}{ Sediment vs Compartment } & \multicolumn{2}{|c|}{ Compartments } & \\
\hline & & & A vs $P$ & A vs $\mathrm{V}$ & V vs $\mathrm{P}$ & Sd vs R & Sd vs Rh & Sd vs L & $\mathrm{R}$ vs $\mathrm{Rh}$ & Rh vs $L$ & \\
\hline \multirow[t]{3}{*}{$\mathrm{Cd}$} & Location & $<0.001$ & $<0.001$ & $<0.001$ & $<0.001$ & & & & & & \\
\hline & Station & $<0.001$ & & & & & & & & & \\
\hline & Compt. & $<0.001$ & & & & $<0.001$ & $<0.001$ & $<0.001$ & $<0.001$ & 0.787 & $<0.001$ \\
\hline \multirow[t]{3}{*}{$\mathrm{Cu}$} & Location & $<0.001$ & 0.626 & $<0.001$ & $<0.001$ & & & & & & \\
\hline & Station & $<0.001$ & & & & & & & & & \\
\hline & Compt. & $<0.001$ & & & & $<0.001$ & 0.621 & $<0.001$ & $<0.001$ & $<0.001$ & $<0.001$ \\
\hline \multirow[t]{3}{*}{$\mathrm{Ni}$} & Location & $<0.001$ & $<0.001$ & 0.853 & $<0.001$ & & & & & & \\
\hline & Station & $<0.001$ & & & & & & & & & \\
\hline & Compt. & $<0.001$ & & & & $<0.001$ & $<0.001$ & $<0.001$ & $<0.001$ & $<0.001$ & $<0.001$ \\
\hline \multirow[t]{3}{*}{$\mathrm{Pb}$} & Location & $<0.001$ & $<0.001$ & $<0.001$ & 0.286 & & & & & & \\
\hline & Station & $<0.001$ & & & & & & & & & \\
\hline & Compt. & $<0.001$ & & & & $<0.001$ & $<0.001$ & $<0.001$ & $<0.001$ & $<0.001$ & $<0.001$ \\
\hline \multirow[t]{3}{*}{$\mathrm{Zn}$} & Location & $<0.001$ & $<0.001$ & $<0.001$ & $<0.001$ & & & & & & \\
\hline & Station & $<0.001$ & & & & & & & & & \\
\hline & Compt. & $<0.001$ & & & & $<0.001$ & $<0.001$ & $<0.001$ & $<0.001$ & 0.910 & $<0.001$ \\
\hline
\end{tabular}

Table 5

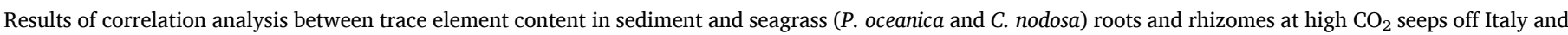

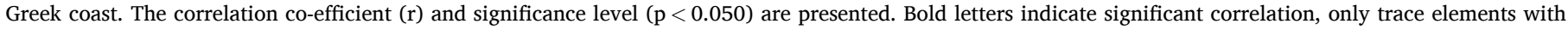
significant correlations are shown.

\begin{tabular}{|c|c|c|c|c|c|c|c|c|}
\hline \multirow{2}{*}{$\frac{\text { Seagrass }}{\text { P. oceanica }}$} & \multirow{2}{*}{$\begin{array}{l}\text { Location } \\
\text { Ischia }\end{array}$} & \multirow{2}{*}{$\begin{array}{l}\text { Element } \\
\mathrm{Zn}\end{array}$} & \multicolumn{4}{|c|}{ Sediment-roots } & \multicolumn{2}{|c|}{ Sediment-rhizomes } \\
\hline & & & $\mathrm{r}$ & & $\mathrm{p}$ value & & $\mathrm{r}$ & $\mathrm{p}$ value \\
\hline & & & -0.234 & & 0.704 & & 0.870 & 0.048 \\
\hline & Panarea & $\mathrm{Cd}$ & 0.841 & & 0.014 & & -0.910 & 0.032 \\
\hline & & $\mathrm{Ni}$ & -0.358 & & 0.554 & & 0.884 & 0.046 \\
\hline \multirow[t]{2}{*}{ C. nodosa } & Vulcano & $\mathrm{Pb}$ & -0.881 & 0.048 & & -0.889 & & 0.037 \\
\hline & & $\mathrm{Zn}$ & -0.795 & 0.108 & & -0.966 & & 0.007 \\
\hline
\end{tabular}

MacDonald, 1998; MacDonald et al., 2000) suggests Hg (at Vulcano), Cu (at Ischia) plus $\mathrm{Cd}$ and $\mathrm{Ni}$ (at Paleochori) were at high enough levels to have adverse impacts on marine biota. So, careful selection of study sites is needed to avoid the combined effects of trace metals and toxic gases while conducting ocean acidification research.
The trace element levels observed within $\mathrm{CO}_{2}$ seep sediments were higher for $\mathrm{Cd}$ (from Methana \& Panarea) and $\mathrm{Cu}$ (from Vulcano \& Ischia), were similar for $\mathrm{Hg}$ (from Ischia, Panarea \& Methana) and lower for $\mathrm{Ni}, \mathrm{Pb}$ and $\mathrm{Zn}$ than mean element levels observed around the Mediterranean coast of Italy (Table 7). The sediments we studied were sandy 
Table 6

Bio-Sediment Accumulation Factor (BSAF) of trace metals in P. oceanica and C. nodosa roots at $\mathrm{CO}_{2}$ seeps (seeps) and Reference (Ref.) stations off Italy and Greek coast. Sediment (Sd), Roots (Ro). Bold numbers indicate BSAF $>1$ value.

\begin{tabular}{|c|c|c|c|c|c|c|c|}
\hline \multirow[t]{3}{*}{ Seagrass } & \multirow{3}{*}{$\frac{\text { Location }}{\text { Elements }}$} & \multirow{2}{*}{\multicolumn{2}{|c|}{$\frac{\text { Ischia }}{\text { BSAF(Ro/Sd) }}$}} & \multirow{2}{*}{\multicolumn{2}{|c|}{$\frac{\text { Panarea }}{\mathrm{BSAF}(\mathrm{Ro} / \mathrm{Sd})}$}} & \multirow{2}{*}{\multicolumn{2}{|c|}{$\frac{\text { Methana }}{\text { BSAF(Ro/Sd) }}$}} \\
\hline & & & & & & & \\
\hline & & Ref. & Seeps. & Ref. & Seeps & Ref. & Seeps \\
\hline \multirow[t]{7}{*}{ P. oceanica } & $\mathrm{Cd}$ & 1.9 & 3.0 & 0.08 & 2.71 & 2.12 & 1.28 \\
\hline & $\mathrm{Cu}$ & 0.17 & 0.29 & 5.15 & 3.10 & 8.21 & 4.49 \\
\hline & $\mathrm{Hg}$ & 0.47 & 0.43 & 1.95 & 0.13 & - & - \\
\hline & $\mathrm{Ni}$ & 1.12 & 1.11 & 0.22 & 1.10 & 3.63 & 3.42 \\
\hline & $\mathrm{Pb}$ & 1.42 & 1.21 & 0.75 & 0.74 & 0.61 & 0.75 \\
\hline & $\mathrm{Zn}$ & 0.81 & 0.56 & 1.12 & 0.52 & 1.70 & 1.87 \\
\hline & & \multicolumn{2}{|c|}{ Vulcano } & \multicolumn{2}{|c|}{ Adamas } & \multicolumn{2}{|c|}{ Paleochori } \\
\hline \multirow[t]{6}{*}{ C. nodosa } & $\mathrm{Cd}$ & 1.71 & 2.23 & 0.45 & 0.52 & 1.03 & 0.03 \\
\hline & $\mathrm{Cu}$ & 1.14 & 4.32 & 36.65 & 6.50 & 1.23 & 1.49 \\
\hline & $\mathrm{Hg}$ & 1.97 & 0.51 & - & - & - & - \\
\hline & $\mathrm{Ni}$ & 0.28 & 3.17 & 2.05 & 1.69 & 0.09 & 0.13 \\
\hline & $\mathrm{Pb}$ & 0.07 & 0.11 & 0.76 & 1.28 & 0.97 & 0.65 \\
\hline & $\mathrm{Zn}$ & 0.50 & 1.13 & 1.62 & 2.27 & 0.90 & 0.62 \\
\hline
\end{tabular}

and lacked the clay particles $(<63 \mu \mathrm{m})$ which bind more trace elements. Trace element levels observed at seep sediments off Vulcano, Italy were in the same range for $\mathrm{Cd}, 5$-fold higher for $\mathrm{Hg}$ and lower for $\mathrm{Cu}$ (1.7fold), $\mathrm{Pb}$ (6-fold) and $\mathrm{Zn}$ (2-fold) from previous measurements by Vizzini et al. (2013). Levels of $\mathrm{Hg}$ and $\mathrm{Pb}$ measured at Panarea $\mathrm{CO}_{2}$ seeps were 5-fold and 4-fold lower from those reported by Renzi et al. (2011), probably because Renzi et al. (2011) sampled just after a massive outgassing event with increased input of elements. Trace element levels in seep sediments of the Greek coast were 3-fold $(\mathrm{Cu}), 2$-fold $(\mathrm{Pb})$ and 1.2-fold (Zn) lower than previously reported by Hodkinson et al. (1994), whereas $\mathrm{Cd}$ and $\mathrm{Ni}$ are reported for the first time for this coast (Table 7). These higher levels of elements could be in part due to weathering and land run-off on-land which makes their way to these shallow volcanic seeps along with hydrothermal inputs (Hodkinson et al., 1994). However, the influence of land run-off (from agricultural inputs and waste water) and tourism can lead to input of various trace metals like $\mathrm{Cu}$ and increase their availability in non-seep areas (Bonanno and Orlando-Bonaca, 2017). This explains why certain reference sites had similar or higher levels of trace metals than seep sites. The difference in element levels within the $\mathrm{CO}_{2}$ seep sediments of Italy and Greece coasts indicates, variation in influx of elements from $\mathrm{CO}_{2}$ seeps. These variations of trace element levels in sediment between $\mathrm{CO}_{2}$ seeps and pristine sites off Greek and Italian coast were also reflected in the plant accumulation of trace elements in roots, rhizomes and leaves (Table 7).

Element levels were higher in seagrass compartments at the seep sites compared to reference sites. Seagrass element accumulation is more element and seagrass tissue-specific rather than species-specific (Bonanno and Orlando-Bonaca, 2017) resulting in seagrass compartments acting as metal accumulators (Govers et al., 2014). In our analyses most elements in both seagrasses were more concentrated in roots than rhizomes than the leaves, which is typical for $P$. oceanica and $C$. nodosa (Bonanno and Orlando-Bonaca, 2017). Root accumulation is common in both terrestrial and aquatic plants where they store and sequester certain elements to avoid damage to photosynthetic apparatus. Seagrasses have different tolerance mechanisms for dealing with trace elements that either accumulate in the roots or are moved out through the leaves which are then shed, as observed in $P$. oceanica (Di Leo et al., 2013; Richir and Gobert, 2016) and in C. nodosa (Malea and Haritinoids, 1999; Bonanno and Di Martino, 2016). This transfer of trace elements from roots to leaves promotes the release of these elements into the food webs of coastal ecosystems or the water column (Richir et al., 2015). On the other hand, storage and sequestration of metals below ground tissues reduces metal release (Windham et al., 2001). Seagrasses accumulate some elements, such as $\mathrm{Cd}$ and $\mathrm{Ni}$, that are essential micronutrients (Sanz-Lazáro et al., 2012) rather than $\mathrm{Hg}$ or $\mathrm{Pb}$ that are toxic
(Kabata-Pendias and Mukherjee, 2007), similar preferences has been observed for accumulation of $\mathrm{Zn}$ over $\mathrm{Pb}$ in both $P$. oceanica (Sanchiz et al., 2001) and C. nodosa (Malea and Haritonidis, 1999; Llagostera et al., 2011). However, seagrasses also tend to store toxic elements like $\mathrm{Hg}$ and $\mathrm{Pb}$ in the vacuoles of cortical tissue of roots outside the endodermis or in cell walls, thereby preventing the uptake of these elements into rhizomes and leaves (Windham et al., 2001).

Significant positive correlation of trace elements between seagrass tissues and sediment suggest the bioindication potential of seagrass tissues for that trace element (Bonanno and Raccuia, 2018). For instance a positive correlation was found in $P$. oceanica for $\mathrm{Cd}$ through the sediment-root pathway and for $\mathrm{Zn}$ and $\mathrm{Ni}$ through sediment to rhizome, which indicates that roots of $P$. oceanica are potential bioindicators of $\mathrm{Cd}$ and rhizomes of $\mathrm{Zn}$ and $\mathrm{Ni}$ at $\mathrm{CO}_{2}$ seeps off Italy. In $C$. nodosa no positive correlation was found for any of the elements analysed, which indicates their low potential for being bioindicators of trace metals and this also suggests why $P$. oceanica is used as a bioindicator in most of trace metal accumulation studies in the Mediterranean Sea (Bonanno et al., 2017). In $P$. oceanica significant negative correlation was found for $\mathrm{Cd}$ in sediment-rhizomes and in $C$. nodosa a negative correlation was found for $\mathrm{Pb}$ between sediment-roots and $\mathrm{Zn}$ between sediment-rhizomes. Negative correlation suggests that the preferable route for Cd transfer in P. oceanica (Lafabrie et al., 2008; Di Leo et al., 2013) and Zn in C. nodosa (Malea and Haritonidis, 1999) is through water column rather than the sediment-root pathways. Similarly, elements such as $\mathrm{Pb}$ with negative correlation in $C$. nodosa, suggests $\mathrm{Pb}$ being toxic is not stored within the seagrass compartments (Sanchiz et al., 2001).

Bio-Sediment Accumulation Factor analysis shows that the pathway of uptake/storage is not always the sediment-root pathways, even though high element concentrations were observed in sediments at $\mathrm{CO}_{2}$ seeps. Even though, in $P$. oceanica $\mathrm{Cd}$ and Ni were found with $\mathrm{BSAF}>1$ in roots at all three seep stations, which suggests that accumulation of elements like $\mathrm{Cd}$ and $\mathrm{Ni}$ are made through the sediment-root pathway for elements like $\mathrm{Cu}, \mathrm{Hg}, \mathrm{Pb}$ and $\mathrm{Zn}$, a mixed response (higher at reference and lower at seep sites or vice versa) of BSAF $>1$ was found, which indicates that for these trace elements both sediment-root and water-root pathways may be used. BSAF $>1$ value observed for trace elements in $P$. oceanica at the $\mathrm{CO}_{2}$ seeps of Italy and Greek coast are within the range of BSAF values observed for $P$. oceanica in the Mediterranean Sea (Bravo et al., 2016). In C. nodosa, Cu was the only element with BSAF $>1$ in roots at all three seep stations, whereas other elements showed mixed responses. $\mathrm{Cu}$ being an essential element is preferred for root accumulation through sediment-root pathway, whereas other elements can use a mixed accumulation from sediment-roots or water roots or water -leaves pathway (Bonanno and Di Martino, 2016). However, in both P. oceanica at Ischia and Panarea and C. nodosa at Vulcano seeps, that $\mathrm{Hg}$ accumulation from sediment-roots pathway (BSAF $>1$ ) was not higher than reference sites, which suggests $\mathrm{Hg}$ being toxic to the plant roots is not preferred for accumulation in seagrass (Bonanno and Di Martino, 2016).

At $\mathrm{CO}_{2}$ seeps the low $\mathrm{pH}$ can alter the metal speciation and favour the release of metals form sediment (Simpson et al., 2004; Atkinson et al., 2007). The chemical form in which metals are present (e.g. whether they are bound to organic or inorganic compounds) is a key issue determining their bioavailability. Low $\mathrm{pH}$ of seawater tends to release metals that are less strongly associated with sediments, increasing their potential bioavailability (Riba et al., 2004). Thus, low pH can increase the concentration of certain dissolved metals, which would affect the sediment-seagrass associated biota e.g., by increasing $\mathrm{Cu}, \mathrm{Cd}$ and $\mathrm{Zn}$ bio-availability, their accumulation and possible toxic effects (Basallote et al., 2014).

In our research, all the $\mathrm{CO}_{2}$ seeps had low $\mathrm{pH}$ (7.4-7.9) conditions, which are known to increase the availability of $\mathrm{Cd}, \mathrm{Cu}, \mathrm{Ni}, \mathrm{Pb}$ and $\mathrm{Zn}$ in their free ion forms (Roberts et al., 2013). Low pH combined with increased availability can influence and increase seagrass uptake of trace elements (Yang and Ye, 2009) that can lead to higher accumulation and storage of trace elements in seagrass roots and leaves (Bonanno and 
Table 7

Mean range of trace element $(\mathrm{mg} / \mathrm{Kg}$ ) levels measured in surface sediments and in P. oceanica and C. nodosa tissues off the coast of Italy and Greece arranged from low to high concentrations. Data collected from literature only included pristine sites containing seagrass meadows around Greece and Italy and seagrass meadows within contaminated sites and sediments taken from ship-based cores were excluded. Samples of $\mathrm{CO}_{2}$ seeps off Italy and Greek coast are indicated in bold. Sediment (Sd), Leaves (L), Rhizomes (Rh), Roots (Ro).

\begin{tabular}{|c|c|c|c|c|c|c|c|c|}
\hline \multirow[t]{2}{*}{ Sediment } & \multirow{2}{*}{$\frac{\text { Sample }}{\text { Sd }}$} & \multirow{2}{*}{$\frac{\mathrm{Cd}}{0.06^{\mathrm{a}}}$} & \multirow{2}{*}{$\frac{\mathrm{Cu}}{-}$} & \multirow{2}{*}{$\begin{array}{l}\mathrm{Hg} \\
-\end{array}$} & \multirow{2}{*}{$\mathrm{Ni}$} & \multirow{2}{*}{$\frac{\mathrm{Pb}}{1.77^{\mathrm{h}}}$} & \multirow{2}{*}{ Zn } & \multirow{2}{*}{$\begin{array}{l}\text { References* } \\
\text { a, h }\end{array}$} \\
\hline & & & & & & & & \\
\hline & Sd & $\begin{array}{l}0.15^{\mathrm{b}} \\
(0.12-0.17)\end{array}$ & $0.20^{\mathrm{k}}$ & - & - & $2.2^{\mathrm{k}}$ & - & $\mathrm{b}, \mathrm{k}$ \\
\hline & Sd & $0.15^{\mathrm{c}}$ & $1.6^{\mathrm{h}}$ & - & - & $\begin{array}{l}2.53^{\mathrm{d}} \\
(2.27-2.74)\end{array}$ & $7.5^{\mathrm{h}}$ & $\mathrm{c}, \mathrm{h}, \mathbf{d}$ \\
\hline & Sd & $\begin{array}{l}0.18^{d} \\
(0.14-0.28)\end{array}$ & $2.03^{\mathrm{a}}$ & - & - & $\begin{array}{l}3.23^{n} \\
(2.76-3.72)\end{array}$ & $10.5^{\mathrm{k}}$ & $\mathrm{d}, \mathrm{a}, \mathrm{n}, \mathrm{k}$ \\
\hline & Sd & $\begin{array}{l}0.22^{\mathrm{e}} \\
(0.19-0.25)\end{array}$ & $\begin{array}{l}2.52^{n} \\
(2.3-2.7)\end{array}$ & - & - & $\begin{array}{l}3.52^{\mathrm{i}} \\
(3.2-3.97)\end{array}$ & $11.4^{\mathrm{c}}$ & $\mathrm{e}, \mathbf{n}, \mathbf{i}, \mathbf{c}$ \\
\hline & Sd & $\begin{array}{l}0.22^{\mathrm{f}} \\
(0.11-0.32)\end{array}$ & $3.04^{\mathrm{c}}$ & - & - & $4.57^{\mathrm{a}}$ & $\begin{array}{l}13.43^{\mathrm{m}} \\
(11.9-15.7)\end{array}$ & $\mathbf{f}, \mathrm{c}, \mathrm{a}, \mathbf{m}$ \\
\hline & Sd & $\begin{array}{l}0.23^{g} \\
(0.15-0.30)\end{array}$ & $\begin{array}{l}3.53^{1} \\
(3.05-3.75)\end{array}$ & - & $\begin{array}{l}1.39^{\mathrm{m}} \\
(0.99-1.39)\end{array}$ & $\begin{array}{l}5.66^{g} \\
(4.31-7)\end{array}$ & $\begin{array}{l}15.67^{1} \\
(11.5-18.7)\end{array}$ & $\mathrm{g}, \mathbf{1 , m}$ \\
\hline & Sd & $0.24^{\mathrm{h}}$ & $\begin{array}{l}5.23 d \\
(4.8-5.6)\end{array}$ & $\begin{array}{l}0.11^{f} \\
(0.01-0.20)\end{array}$ & $\begin{array}{l}1.84^{j} \\
\left(0.85^{-2.20}\right)\end{array}$ & $6.22^{c}$ & $\begin{array}{l}24.54^{d} \\
(14.7-28)\end{array}$ & $h, d, f, j, c$ \\
\hline & Sd & $\begin{array}{l}0.26^{\mathrm{i}} \\
(0.23-0.31)\end{array}$ & $\begin{array}{l}6.24^{\mathrm{e}} \\
(5.23-7.25)\end{array}$ & $\begin{array}{l}0.14^{\mathrm{e}} \\
(0.1-0.17)\end{array}$ & $3.23^{\mathrm{k}}$ & $\begin{array}{l}9.41^{1} \\
(9-10)\end{array}$ & $\begin{array}{l}27.35^{j} \\
(24.3-30.7)\end{array}$ & $\mathrm{i}, \mathrm{e}, \mathrm{k}, \mathbf{1}, \mathbf{j}$ \\
\hline & Sd & $\begin{array}{l}0.26^{\mathrm{j}} \\
(0.23-0.29)\end{array}$ & $\begin{array}{l}6.68^{0} \\
(6.01-6.91)\end{array}$ & $\begin{array}{l}0.39^{g} \\
(0.18-0.60)\end{array}$ & $5.4^{\mathrm{c}}$ & $\begin{array}{l}11.52^{\mathrm{m}} \\
(11.1-14.8)\end{array}$ & $31.75^{\mathrm{a}}$ & $\mathbf{j}, \mathbf{o}, \mathrm{g}, \mathrm{c}, \mathrm{m}, \mathrm{a}$ \\
\hline & Sd & $0.3^{\mathrm{k}}$ & $\begin{array}{l}15.15^{\mathrm{b}} \\
(8.0-22.3)\end{array}$ & $\begin{array}{l}0.59^{\mathrm{m}} \\
(0.38-0.95)\end{array}$ & $\begin{array}{l}6.91^{1} \\
(5.6-8.9)\end{array}$ & $\begin{array}{l}14.25^{j} \\
(12.05-15.3)\end{array}$ & $\begin{array}{l}35.74^{\mathrm{n}} \\
(31.2-35.8)\end{array}$ & $\mathrm{k}, \mathrm{b}, \mathbf{m}, \mathbf{l}, \mathbf{j}, \mathbf{n}$ \\
\hline & Sd & $\begin{array}{l}0.35^{1} \\
(0.30-0.38)\end{array}$ & $18^{\mathrm{p}}$ & $\begin{array}{l}0.60^{j} \\
(0.55-0.67)\end{array}$ & $\begin{array}{l}9.01^{\mathrm{i}} \\
(8-9.87)\end{array}$ & $\begin{array}{l}15.40^{\mathrm{f}} \\
(5.8-25.0)\end{array}$ & $43^{\mathrm{h}}$ & $1, p, j, i, f, h$ \\
\hline & Sd & $\begin{array}{l}0.67^{\mathrm{m}} \\
(0.18-0.98)\end{array}$ & $\begin{array}{l}36.15^{\mathrm{i}} \\
(29.41-44.80)\end{array}$ & $\begin{array}{l}0.83^{i} \\
(0.74-1.09)\end{array}$ & $\begin{array}{l}13.47^{n} \\
(10-17)\end{array}$ & $20^{\mathrm{p}}$ & $\begin{array}{l}43.05^{\mathrm{b}} \\
(35-68)\end{array}$ & $\mathrm{m}, \mathrm{i}, \mathrm{n}, \mathrm{p}, \mathrm{b}$ \\
\hline & Sd & $\begin{array}{l}0.89^{n} \\
(0.76-0.97)\end{array}$ & $\begin{array}{l}51.25 f \\
(26.4-76.1)\end{array}$ & $\begin{array}{l}0.95^{\mathrm{b}} \\
(0.1-1.79)\end{array}$ & $\begin{array}{l}43.37^{d} \\
(35.2-48.1)\end{array}$ & $\begin{array}{l}21.65^{\mathrm{b}} \\
(14.2-29.1)\end{array}$ & $\begin{array}{l}46^{f} \\
(13.8-78.2)\end{array}$ & $\mathbf{n}, \mathbf{f}, \mathrm{b}, \mathrm{d}$ \\
\hline & Sd & $1^{0}$ & $\begin{array}{l}114^{\mathrm{j}} \\
(113-116)\end{array}$ & $4.5^{\circ}$ & $\begin{array}{l}46.1^{\mathrm{e}} \\
(39.8-52.4)\end{array}$ & $60^{\circ}$ & $\begin{array}{l}51.5^{\mathrm{e}} \\
(31.4-54.7)\end{array}$ & $\mathbf{o}, \mathbf{j}, \mathrm{e}$ \\
\hline \multirow[t]{21}{*}{ P. oceanica } & $\mathrm{L}$ & $\begin{array}{l}0.23^{1} \\
(0.10-0.29)\end{array}$ & $\begin{array}{l}1.90^{4} \\
(1.01-2.79\end{array}$ & $\begin{array}{l}0.025^{\mathrm{r}} \\
(0.01-0.04)\end{array}$ & $\begin{array}{l}1.03^{\mathrm{m}} \\
(0.82-1.47)\end{array}$ & $\begin{array}{l}0.33^{\mathrm{q}} \\
(0.15-0.52)\end{array}$ & $\begin{array}{l}23.9^{1} \\
(21.07-26.99)\end{array}$ & $1, \mathrm{q}, \mathrm{r}, \mathrm{m}$ \\
\hline & $\mathrm{L}$ & $\begin{array}{l}0.30^{\mathrm{q}} \\
(0.22-0.38)\end{array}$ & $\begin{array}{l}6.89^{j} \\
(5.47-8.72)\end{array}$ & $\begin{array}{l}0.095^{\mathrm{w}} \\
(0.01-0.18)\end{array}$ & $\begin{array}{l}1.95^{\mathrm{j}} \\
(1.81-2.81)\end{array}$ & $\begin{array}{l}1.18^{r} \\
(0.4-1.96)\end{array}$ & $55.7^{\mathrm{k}}$ & $\mathrm{q}, \mathbf{j}, \mathrm{w}, \mathrm{r}, \mathrm{k}$ \\
\hline & $\mathrm{L}$ & $\begin{array}{l}0.62^{\mathrm{j}} \\
(0.49-0.77)\end{array}$ & $\begin{array}{l}7.39^{1} \\
(6.2-8.6)\end{array}$ & $\begin{array}{l}0.33^{\mathrm{m}} \\
(0.23-0.41)\end{array}$ & $\begin{array}{l}3.32^{\mathrm{q}} \\
(1.44-5.21)\end{array}$ & $\begin{array}{l}1.53^{\mathrm{m}} \\
(1.51-1.89)\end{array}$ & $\begin{array}{l}86.25^{\mathrm{u}} \\
(16.5-156)\end{array}$ & $\mathrm{j}, \mathrm{l}, \mathrm{m}, \mathrm{q}, \mathrm{u}$ \\
\hline & $\mathrm{L}$ & $\begin{array}{l}0.64^{\mathrm{m}} \\
(0.48-0.84)\end{array}$ & $\begin{array}{l}10.41^{\mathrm{u}} \\
(3.12-17.7)\end{array}$ & $\begin{array}{l}0.42^{j} \\
(0.15-0.62)\end{array}$ & $9.5^{\mathrm{k}}$ & $\begin{array}{l}1.69^{j} \\
(1.32-1.87)\end{array}$ & $\begin{array}{l}115.5^{j} \\
(110.5-119.8)\end{array}$ & $\mathrm{m}, \mathrm{u}, \mathrm{j}, \mathrm{k}$ \\
\hline & $\mathrm{L}$ & $\begin{array}{l}1.08^{r} \\
(0.4-1.76)\end{array}$ & $10.5^{\mathrm{k}}$ & - & $\begin{array}{l}12.34^{1} \\
(10.81-17.74)\end{array}$ & $2.1^{\mathrm{k}}$ & $\begin{array}{l}201^{\mathrm{v}} \\
(142-260)\end{array}$ & $\mathrm{r}, \mathrm{k}, \mathrm{l}, \mathrm{v}$ \\
\hline & $\mathrm{L}$ & $\begin{array}{l}1.30^{\mathrm{s}} \\
(0.60-2.0)\end{array}$ & $\begin{array}{l}11.51^{\mathrm{s}} \\
(6-17.02)\end{array}$ & - & $21.2^{\mathrm{t}}$ & $\begin{array}{l}2.86^{1} \\
(0.33-8.29)\end{array}$ & $\begin{array}{l}390.3^{\mathrm{m}} \\
(342.5-424.1)\end{array}$ & $\mathrm{s}, \mathrm{t}, \mathbf{1}, \mathrm{m}$ \\
\hline & $\mathrm{L}$ & $1.45^{\mathrm{k}}$ & $\begin{array}{l}36.50^{\mathrm{v}} \\
(19.8-53.2)\end{array}$ & - & $\begin{array}{l}41^{x} \\
(21.1-60.9)\end{array}$ & $\begin{array}{l}3.05^{\mathrm{v}} \\
(1.1-5)\end{array}$ & - & $\mathrm{k}, \mathrm{v}, \mathrm{x}, \mathrm{v}$ \\
\hline & $\mathrm{L}$ & $1.99^{t}$ & $\begin{array}{l}41.26^{\mathrm{m}} \\
(35.93-47.80)\end{array}$ & - & - & $\begin{array}{l}7.19^{\mathrm{u}} \\
(0.59-13.8)\end{array}$ & - & $\mathrm{t}, \mathrm{m}, \mathrm{u}$ \\
\hline & $\mathrm{L}$ & $\begin{array}{l}3.22^{\mathrm{u}} \\
(0.95-5.49)\end{array}$ & - & - & - & $\begin{array}{l}8.2^{\mathrm{s}} \\
(5.2-11.2)\end{array}$ & - & $\mathrm{u}, \mathrm{s}$ \\
\hline & $\mathrm{L}$ & $\begin{array}{l}5.55^{\mathrm{v}} \\
(3.6-7.5)\end{array}$ & - & - & - & - & - & $\mathrm{v}$ \\
\hline & $\mathrm{Rh}$ & $\begin{array}{l}0.24^{1} \\
(0.22-0.27)\end{array}$ & $\begin{array}{l}6.3^{1} \\
(4.92-6.88)\end{array}$ & $\begin{array}{l}0.1^{\mathrm{m}} \\
(0.08-0.17)\end{array}$ & $2.34^{\mathrm{k}}$ & $\begin{array}{l}0.48^{\mathrm{m}} \\
(0.18-1.11)\end{array}$ & $\begin{array}{l}8.67^{\mathrm{m}} \\
(8.87-9.65)\end{array}$ & $\mathrm{l}, \mathrm{m}, \mathrm{k}$ \\
\hline & $\mathrm{Rh}$ & $0.89^{k}$ & $\begin{array}{l}8.67^{\mathrm{m}} \\
(7.9-9.82)\end{array}$ & $\begin{array}{l}0.16^{j} \\
(0.12-0.19)\end{array}$ & $3.34^{x}$ & $\begin{array}{l}1.6^{\mathrm{s}} \\
(0.8-2.4)\end{array}$ & $32.5^{\mathrm{k}}$ & $\mathrm{k}, \mathrm{m}, \mathbf{j}, \mathrm{x}, \mathrm{s}$ \\
\hline & & $\begin{array}{l}1.15^{\mathrm{v}} \\
(0.6-1.7)\end{array}$ & $\begin{array}{l}10.35^{\mathrm{s}} \\
(5.4-15.3)\end{array}$ & - & $\begin{array}{l}3.6^{\mathrm{m}} \\
(3.1-3.97)\end{array}$ & $\begin{array}{l}4.45^{1} \\
(2.78-7.29)\end{array}$ & $\begin{array}{l}32.99^{j} \\
(29.44-34.57)\end{array}$ & $\mathrm{v}, \mathrm{s}, \mathrm{m}, \mathbf{l}, \mathbf{j}$ \\
\hline & $\mathrm{Rh}$ & $\begin{array}{l}1.6^{\mathrm{s}} \\
(0.8-2.4)\end{array}$ & $\begin{array}{l}11.85^{\mathrm{v}} \\
(9.4-14.3)\end{array}$ & - & $\begin{array}{l}5.78^{j} \\
(5.21-6.26)\end{array}$ & $\begin{array}{l}4.92^{j} \\
(3.82-5.64)\end{array}$ & $\begin{array}{l}46.97^{1} \\
(43.61-48.55)\end{array}$ & $\mathrm{s}, \mathrm{v}, \mathbf{j}, \mathbf{l}$ \\
\hline & $\mathrm{Rh}$ & $\begin{array}{l}2.48^{\mathrm{m}} \\
(2.26-2.69)\end{array}$ & $\begin{array}{l}14.29^{j} \\
(13.25-15.25)\end{array}$ & - & $\begin{array}{l}15.68^{1} \\
(10.98-19.93)\end{array}$ & $\begin{array}{l}14.02^{\mathrm{V}} \\
(0.03-28)\end{array}$ & $58^{\mathrm{u}}$ & $\mathrm{m}, \mathrm{j}, \mathrm{l}, \mathrm{v}, \mathrm{u}$ \\
\hline & $\mathrm{Rh}$ & $\begin{array}{l}4.76^{j} \\
(4.43-5.58)\end{array}$ & $\begin{array}{l}29.51^{x} \\
(0.41-58.6)\end{array}$ & - & - & - & - & $\mathrm{j}, \mathrm{x}$ \\
\hline & Ro & $1.8^{\mathrm{k}}$ & $14.6^{\mathrm{k}}$ & $\begin{array}{l}0.38^{\mathrm{m}} \\
(0.18-0.53)\end{array}$ & $5.12^{\mathrm{k}}$ & $2.56^{\mathrm{k}}$ & $44.3^{\mathrm{k}}$ & $\mathrm{k}, \mathbf{m}$ \\
\hline & Ro & $\begin{array}{l}0.45^{1} \\
(0.29-0.67)\end{array}$ & $\begin{array}{l}15.78^{1} \\
(14.96-16.55)\end{array}$ & $\begin{array}{l}0.73^{j} \\
(0.6-0.94)\end{array}$ & $\begin{array}{l}4.35^{j} \\
(3.79-4.95)\end{array}$ & $\begin{array}{l}1.65^{\mathrm{m}} \\
(1.52-1.7)\end{array}$ & $\begin{array}{l}15.66^{\mathrm{m}} \\
(14.23-18.85)\end{array}$ & $1, \mathrm{j}, \mathrm{m}$ \\
\hline & Ro & $\begin{array}{l}0.55^{\mathrm{m}} \\
(0.36-0.74)\end{array}$ & $\begin{array}{l}18.18^{\mathrm{x}} \\
(0.25-36.1)\end{array}$ & - & $\begin{array}{l}7.36^{\mathrm{m}} \\
(6.96-7.96)\end{array}$ & $\begin{array}{l}6.01^{j} \\
(5.23-7)\end{array}$ & $\begin{array}{l}17.85^{j} \\
(15.11-19.32)\end{array}$ & $\mathbf{m}, \mathrm{x}, \mathrm{j}$ \\
\hline & Ro & $\begin{array}{l}0.76^{j} \\
(0.53-0.89)\end{array}$ & $\begin{array}{l}33.65^{j} \\
(33.77-35.67)\end{array}$ & - & $\begin{array}{l}22.88^{1} \\
(21.6-24.79)\end{array}$ & $\begin{array}{l}7.03^{1} \\
(6.22-7.77)\end{array}$ & $\begin{array}{l}27.41^{1} \\
(23.38-26.83)\end{array}$ & $\mathrm{j}, 1$ \\
\hline & Ro & - & & - & & - & - & $\mathbf{m}, \mathrm{x}$ \\
\hline
\end{tabular}


Table 7 (continued)

\begin{tabular}{|c|c|c|c|c|c|c|c|c|}
\hline \multirow[t]{2}{*}{ Sediment } & \multirow{2}{*}{$\frac{\text { Sample }}{\text { Sd }}$} & \multirow{2}{*}{$\frac{\mathrm{Cd}}{0.06^{\mathrm{a}}}$} & \multirow{2}{*}{$\frac{\mathrm{Cu}}{-}$} & \multirow{2}{*}{$\frac{\mathrm{Hg}}{-}$} & \multirow{2}{*}{$\frac{\mathrm{Ni}}{-}$} & \multirow{2}{*}{$\frac{\mathrm{Pb}}{1.77^{\mathrm{h}}}$} & \multirow{2}{*}{$\frac{\mathrm{Zn}}{-}$} & \multirow{2}{*}{$\frac{\text { References* }}{\mathrm{a}, \mathrm{h}}$} \\
\hline & & & & & & & & \\
\hline & & & $\begin{array}{l}37.21^{\mathrm{m}} \\
(35.21-38.21)\end{array}$ & & $\begin{array}{l}24.77^{\mathrm{x}} \\
(3.44-46.2)\end{array}$ & & & \\
\hline \multirow[t]{21}{*}{ C. nodosa } & $\mathrm{L}$ & $\begin{array}{l}0.15^{n} \\
(0.14-0.18)\end{array}$ & $2.1^{\mathrm{x}}$ & $\begin{array}{l}0.53^{g} \\
(0.36-0.70)\end{array}$ & $2.33^{\mathrm{z}}$ & $\begin{array}{l}0.23^{n} \\
(0.09-0.39)\end{array}$ & $\begin{array}{l}13.30^{d} \\
(11.89-15.33)\end{array}$ & $\mathbf{n}, \mathrm{x}, \mathrm{g}, \mathrm{z}, \mathbf{d}$ \\
\hline & $\mathrm{L}$ & $\begin{array}{l}0.21^{\mathrm{d}} \\
(0.18-0.23)\end{array}$ & $\begin{array}{l}3.21^{\mathrm{d}} \\
(2.77-3.88)\end{array}$ & $0.54^{\mathrm{i}}$ & $\begin{array}{l}2.76^{\mathrm{n}} \\
(2.33-3.65)\end{array}$ & $\begin{array}{l}1.69^{d} \\
(1.12-2.29)\end{array}$ & $\begin{array}{l}24.12^{n} \\
(21.47-26.49)\end{array}$ & $\mathbf{d}, \mathrm{i}, \mathbf{n}$ \\
\hline & $\mathrm{L}$ & $0.55^{\mathrm{c}}$ & $3.9^{c}$ & - & $2.80^{\mathrm{x}}$ & $1.85^{\mathrm{c}}$ & $\begin{array}{l}30.94^{i} \\
(26.48-38.65)\end{array}$ & $\mathrm{c}, \mathrm{x}, \mathrm{i}$ \\
\hline & $\mathrm{L}$ & $\begin{array}{l}0.86^{i} \\
(0.37-1.74)\end{array}$ & $\begin{array}{l}6.63^{n} \\
(6.07-7.28)\end{array}$ & - & $\begin{array}{l}4.44^{\mathrm{d}} \\
(4.12-4.89)\end{array}$ & $\begin{array}{l}3.29^{i} \\
(2.58-3.80)\end{array}$ & $43.4^{c}$ & $i, n, d$ \\
\hline & $\mathrm{L}$ & $\begin{array}{l}1.03^{\mathrm{f}} \\
(0.45-1.61)\end{array}$ & $9.6^{y}$ & - & $5.57^{\mathrm{c}}$ & $\begin{array}{l}5.56^{f} \\
(2.86-8.26)\end{array}$ & $57.5^{y}$ & f, $y, c$ \\
\hline & $\mathrm{L}$ & $1.2^{\mathrm{y}}$ & $\begin{array}{l}12.67^{i} \\
(10.52-14.74)\end{array}$ & - & $7.6^{y}$ & $\begin{array}{l}18.37^{\mathrm{g}} \\
(3.32-33.42)\end{array}$ & - & $y, \mathbf{i}, g$ \\
\hline & $\mathrm{L}$ & $\begin{array}{l}2.10^{g} \\
(0.39-3.82)\end{array}$ & - & - & $\begin{array}{l}9.41^{\mathrm{i}} \\
(7.13-10.71)\end{array}$ & - & - & $\mathrm{g}, \mathrm{i}$ \\
\hline & $\mathrm{Rh}$ & $\begin{array}{l}0.14^{d} \\
(0.12-0.16)\end{array}$ & $2.06^{\mathrm{c}}$ & $\begin{array}{l}0.18^{i} \\
(0.17-0.19)\end{array}$ & $1.15^{\mathrm{c}}$ & $0.38^{c}$ & $24.2^{\mathrm{c}}$ & $\mathrm{d}, \mathrm{c}, \mathrm{i}$ \\
\hline & $\mathrm{Rh}$ & $\begin{array}{l}0.15^{\mathrm{i}} \\
(0.12-0.20)\end{array}$ & $\begin{array}{l}2.29^{d} \\
(2.03-2.66)\end{array}$ & - & $0.85^{\mathrm{z}}$ & $\begin{array}{l}1.69^{i} \\
(0.53-3.26)\end{array}$ & $\begin{array}{l}17.36^{\mathrm{d}} \\
(14.65-19.54)\end{array}$ & $\mathrm{d}, \mathrm{z}, \mathrm{i}$ \\
\hline & $\mathrm{Rh}$ & $\begin{array}{l}0.56^{n} \\
(0.52-0.67)\end{array}$ & $\begin{array}{l}3.76^{n} \\
(3.74-3.79)\end{array}$ & - & $1.2^{\mathrm{y}}$ & $\begin{array}{l}1.74^{d} \\
(1.61-1.94)\end{array}$ & $\begin{array}{l}21.66^{n} \\
(19.97-23.60)\end{array}$ & $\mathbf{n}, \mathrm{y}, \mathbf{d}$ \\
\hline & $\mathrm{Rh}$ & $2.1^{\mathrm{y}}$ & $\begin{array}{l}5.64^{\mathrm{x}} \\
(0.19-11.10)\end{array}$ & - & $\begin{array}{l}2.42^{\mathrm{d}} \\
(2.39-2.57)\end{array}$ & $\begin{array}{l}2.34^{\mathrm{n}} \\
(2.01-2.67)\end{array}$ & $23^{y}$ & $\mathrm{y}, \mathrm{x}, \mathbf{d}, \mathbf{n}$ \\
\hline & $\mathrm{Rh}$ & - & $7.7^{y}$ & - & $\begin{array}{l}2.61^{\mathrm{n}} \\
(2.11-3.58)\end{array}$ & - & $\begin{array}{l}26.78^{i} \\
(25.08-28.47)\end{array}$ & $\mathrm{y}, \mathbf{n}, \mathbf{i}$ \\
\hline & $\mathrm{Rh}$ & - & $\begin{array}{l}24.41^{\mathrm{i}} \\
(21.57-26.86)\end{array}$ & - & $\begin{array}{l}2.88^{\mathrm{i}} \\
(2.49-3.71)\end{array}$ & - & - & i \\
\hline & $\mathrm{Rh}$ & - & - & - & $\begin{array}{l}5.17^{x} \\
(1.4-8.95)\end{array}$ & - & - & $\mathrm{x}$ \\
\hline & Ro & $0.21^{\mathrm{c}}$ & $3.35^{c}$ & $0.4^{i}$ & $3.45^{c}$ & $4.56^{c}$ & $35.3^{c}$ & $\mathrm{c}, \mathbf{i}$ \\
\hline & Ro & $\begin{array}{l}0.19^{d} \\
(0.14-0.27)\end{array}$ & $\begin{array}{l}7.71^{d} \\
(6.76-8.21)\end{array}$ & - & $\begin{array}{l}0.34^{\mathrm{z}} \\
(0.34-5.04)\end{array}$ & $\begin{array}{l}0.91^{\mathrm{i}} \\
(0.81-1.05)\end{array}$ & $\begin{array}{l}9.72^{n} \\
(8.90-10.79)\end{array}$ & $\mathbf{d}, \mathrm{z}, \mathbf{i}, \mathbf{n}$ \\
\hline & Ro & $\begin{array}{l}0.81^{\mathrm{i}} \\
(0.78-0.80)\end{array}$ & $12.8^{\mathrm{y}}$ & - & $\begin{array}{l}2.33^{n} \\
(1.64-3.01)\end{array}$ & $\begin{array}{l}1.62^{d} \\
(1.42-1.85)\end{array}$ & $\begin{array}{l}14.64^{d} \\
(12.82-17.44)\end{array}$ & $\mathbf{i}, \mathrm{y}, \mathbf{n}, \mathbf{d}$ \\
\hline & Ro & $\begin{array}{l}1.13^{n} \\
(1.10-1.14)\end{array}$ & $\begin{array}{l}16.39^{n} \\
(14.04-18.96)\end{array}$ & - & $\begin{array}{l}3.4^{\mathrm{x}} \\
(3.4-50)\end{array}$ & $\begin{array}{l}9.02^{n} \\
(8.04-9.81)\end{array}$ & $22.92^{y}$ & $\mathbf{n}, \mathrm{x}, \mathrm{y}$ \\
\hline & Ro & $2.1^{\mathrm{y}}$ & $\begin{array}{l}38.26^{\mathrm{x}} \\
(1.11-75.4)\end{array}$ & - & $5.2^{y}$ & - & $\begin{array}{l}79.52^{i} \\
(76.11-82.84)\end{array}$ & $\mathrm{y}, \mathrm{x}, \mathbf{i}$ \\
\hline & Ro & - & $\begin{array}{l}253^{i} \\
(248.4-258.40)\end{array}$ & - & $\begin{array}{l}5.75^{\mathrm{d}} \\
(5.19-6.37)\end{array}$ & - & - & $\mathrm{i}, \mathrm{d}$ \\
\hline & Ro & - & & - & $\begin{array}{l}38.67^{i} \\
(32-48)\end{array}$ & - & - & $\mathrm{i}$ \\
\hline
\end{tabular}

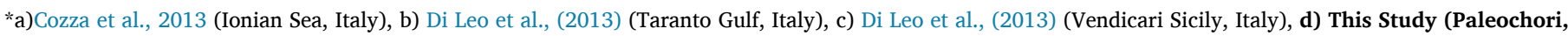

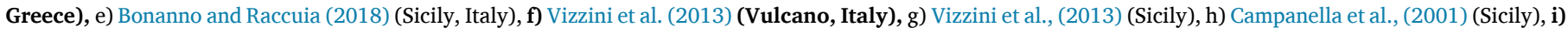

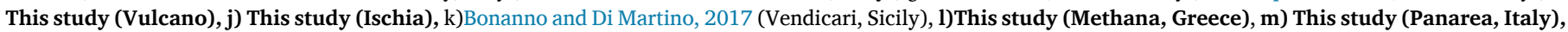

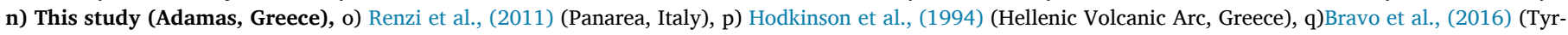

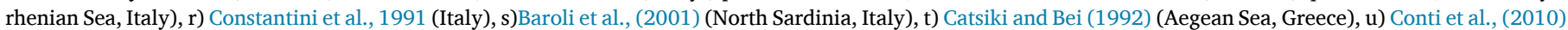

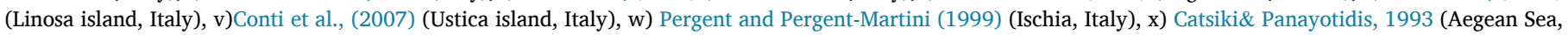
Greece), y) Nicolaidou and Nott (1998) (North Evvoikos Gulf, Greece), z) Malea and Kevrekidis (2013) (Thessaloniki Gulf, Greece).

Orlando-Bonaca, 2017). Higher accumulation can lead to metal stress once threshold levels are reached and affect the seagrass physiological processes (Olivé et al., 2017). However, it is difficult to measure toxic effects of metals on seagrass in in-situ conditions due to variable environmental settings, but few ex-situ studies on metal toxicity have been conducted on Cymodocea serrulata (Prange and Dennison, 2000), Halophila ovalis and H. spinulosa (Prange and Dennison, 2000; Ambo-Rappe et al., 2011). Considering the observed results from these ex-situ metal toxicity studies, there is a possibility that elements such as $\mathrm{Cu}$ and $\mathrm{Pb}$ at the $\mathrm{CO}_{2}$ seeps may affect $P$. oceanica and $C$. nodosa photosynthesis as well as root and leaf structures (Prange and Dennison, 2000; Ambo-Rappe et al., 2011). This may be why seagrasses are abundant at some seeps but not at others.

\section{Conclusion}

We observed that Greek and Italian marine $\mathrm{CO}_{2}$ seeps had elevated levels of trace elements in sediments compared to reference sites, and that this can be used to investigate interactions between seawater $\mathrm{pH}$, element bioavailability and element accumulation within marine organisms. Care is needed when using volcanic $\mathrm{CO}_{2}$ seeps as analogues for the effects of ocean acidification as increased levels of trace elements can be harmful to marine biota. In some cases, such as Ischia, high levels of $\mathrm{Cu}$ in the sediment were not accumulated in seagrass. At other sites low $\mathrm{pH}$ increased the accumulation of trace metals in seagrass, such as with Zn off Vulcano, Panarea and Ischia. Our research shows that ocean acidification can affect the bioaccumulation of some trace elements, which is relevant to agencies responsible for monitoring the effects of contamination in the marine environment.

\section{Declaration of competing interest}

The authors AK Mishra, Rui Santos and Jason Hall Spencer declare there is no conflict of interest between any organization or individuals regarding the manuscript. 


\section{Acknowledgement}

This work was part of MARES 'Future Oceans' project (MARES _12_14) and was funded through a MARES Grant. MARES is a Joint Doctorate programme selected under Erasmus Mundus coordinated by Ghent University (FPA 2011-0016). This study received Portuguese national funds from FCT-Foundation for Science and Technology through project UID/Muli/04326/2019.We are grateful to Dr Marco Milazzo for his support during the field work at Vulcano, Italy. Dr Joao Silva and Dr Irene Oliva for helping collect samples from Ischia and Panarea, Italy. We are grateful for the support of Thanos Dailianis, Julius Glampedakis in collection of samples from Greece and Dr Eugenia Apostolaki for her support during the field work. We are thankful to Andrew Tonkin and Robert Clough at Plymouth University, UK for helping in laboratory analysis. We would like to thank Prof. Paul Dando and Prof. Franceso Parello for their constructive comments on an early draft.

\section{Appendix A. Supplementary data}

Supplementary data to this article can be found online at https://doi. org/10.1016/j.marenvres.2019.104810.

\section{References}

Agostini, S., Harvey, B.P., Wada, S., Kon, K., et al., 2018. Ocean acidification drives community shift towards simplified non-calcified habitats in a subtropical-temperate transition zone. Sci. Rep. 8, 11354. https://doi.org/10.1038/s41598-018-29251-7.

Aiuppa, A., Dongarrà, G., Capasso, G., Allard, P., 2000. Trace elements in the thermal ground waters of Vulcano Island (Sicily). J. Volcanol. Geotherm. Res. 98, 189-207.

Ambo Rappe, R., Lajus, D.L., Schreider, M.J., 2007. Translational fluctuating asymmetry and leaf dimension in seagrass, Zostera capricorni Aschers in a gradient of heavy metals. Environ. Bioindic. 2, 99-116.

Ambo-Rappe, R., Lajus, D.L., Schreider, M.J., 2011. Heavy metal impact on growth and leaf asymmetry of seagrass Halophila ovalis. Jour. Of. Envir. Chem. and Ecotox. 6, $145-149$.

Apostolaki, E.T., Vizzini, S., Hendriks, I.E., Olsen, Y.S., 2014. Seagrass ecosystem response to long-term high $\mathrm{CO}_{2}$ in a Mediterranean volcanic vent. Mar. Environ. Res. 99, 9-15.

Atkinson, C.A., Jolley, D.F., Simpson, S.L., 2007. Effect of overlying water pH, dissolved oxygen, salinity and sediment disturbances on metal release and sequestration from metal contaminated marine sediments. Chemosphere 9, 1428-1437.

Avelar, M., Bonilla-Heredia, B., Merino-Ibarra, M., Herrera-Silveira, J.A., et al., 2013. Iron, cadmium, and chromium in seagrass (Thalassia testudinum) from a coastal nature reserve in karstic Yucatan. Environ. Monit. Assess. 185, 7591-7603.

Baggini, C., Salomidi, M., Voutsinas, E., Bray, L., et al., 2014. Seasonality affects macroalgal community response to increase in $\mathrm{pCO}_{2}$. PLoS One 9, 1-13.

Baroli, M., Cristini, A., Cossi, A., DeFalco, G., et al., 2001. Concentrations of trace metals in Posidonia oceanica seagrass of Liscia bay, Sardinia (Italy), chapter 13. In: Faranda, L., Guglielmo, G.S. (Eds.), Mediterranean Ecosystems: Structures and Processes. Spring- er-Verlag, Milan, Italy, pp. 95-99.

Barry, J.P., Hall-Spencer, J.M., Tyrrell, T., 2010. In situ perturbation experiments: natural venting site, spatial/temporal gradients in ocean $\mathrm{pH}$, manipulative in situ $\mathrm{pCO}_{2}$ perturbations. In: Riebesell, U., Fabry, V.J., Hansson, L., Gattuso, J.-P. (Eds.), Guide to Best Practices for Ocean Acidification Research and Data Reporting. Publications Office of the European Union, Luxembourg, pp. 123-136.

Basallote, M.D., De Orte, M.R., DelValls, T.A., Riba, I., 2014. Studying the effect of $\mathrm{CO}_{2}$ induced acidfication on sediment toxicity using acute amphipod toxicity test. Environ. Sci. Technol. 48 (15), 8864-8872.

Batley, G.E., Apte, S.C., Stauber, J.L., 2004. Speciation and bioavailability of trace metals in water: progress since 1982. Aust. J. Chem. 57, 903-919.

Bayraktarov, E., Price, R.E., Ferdelman, T.G., Finster, K., 2013. The pH and $\mathrm{pCO}_{2}$ dependence of sulfate reduction in shallow-sea hydrothermal $\mathrm{CO}_{2}$-venting sediments (Milos Island, Greece). Front. Microbiol. 4, 1-10.

Besar, S.N.T., Shazili, N.A.M., Abdullah, S.A., Mamat, A.S., 2008. Experimental and field study on accumulation of heavy metals. J. of Sustain. And Manag. 3, 41-73.

Blott, S.J., Pye, K., 2001. GRADISTAT: a grain size distribution and statistics package for the analysis of unconsolidated sediments. Earth Sur. Pro. and Landfo. 26, 1237-1248.

Boatta, F., D'Alessandro, W., Gagliano, A.L., Liotta, et al., 2013. Geochemical survey of Levante bay, Vulcano island (Italy), a natural laboratory for the study of ocean acidification. Mar. Pollut. Bull. 73, 485-494.

Bonanno, G., Di Martino, V., 2016. Seagrass Cymodocea nodosa as a trace element bio monitor: bioaccumulation patterns and biomonitoring uses. J. Geochem. Explor. $169,43-49$.

Bonanno, G., Di Martino, V., 2017. Trace element compartmentation in the seagrass Posidonia oceanica and biomonitoring applications. Mar. Pollut. Bull. 116, 196-203. https://doi.org/10.1016/j.marpolbul.2016.12.081.
Bonanno, G., Orlando-Bonaca, M., 2017. Trace element in Mediterranean seagrasses: accumulation, tolerance and biomonitoring. A review. Mar. Pollut. Bull. 125, 8-18.

Bonanno, G., Borg, J.A., Di Martino, V., 2017. Levels of heavy metals in wetland and marine vascular plants and their biomonitoring potential: a comparative assessment. Sci. Total Environ. 576, 796-806.

Bonanno, G., Raccuia, S.A., 2018. Seagrass Halophila stipulacea: capacity of accumulation and biomonitoring of trace elements. Sci. Total Environ. 633, 257-263.

Bravo, I., Focaracci, F., Cerfolli, F., Papetti, P., 2016. Relationships between trace elements in Posidonia oceanica shoots and in sediment fractions along Latium coasts (north- western Mediterranean Sea). Environ. Monit. Assess. 188, 157.

Brodie, J., Williamson, C., Smale, D.A., Kamenos, N.A., et al., 2014. The future of the northeast Atlantic benthic flora in a high $\mathrm{CO}_{2}$ world. Ecol. Evol. 13, 2787-2798.

Byrne, R.H., Kump, L., Cantrell, K., 1988. The influence of temperature and pH on trace metal speciation in seawater. Mar. Chem. 25, 163-181.

Caeiro, S., Costa, M.H., Ramos, T.B., 2005. Assessing heavy metal contamination in Sado Estuary sediment: an index analysis approach. Ecol. Indicat. 5, 151-169.

Caldeira, K., Wickett, M.E., 2003. Oceanography: anthropogenic carbon and ocean pH. Nature 425, 365.

Campanella, L., Conti, M.E., Cubadda, F., Sucapane, C., 2001. Trace metals in seagrass, algae and molluscs from an uncontaminated area in the Mediterranean. Environ. Pollut. 111, 117-126.

Capaccioni, B., Tassi, F., Vaselli, O., 2001. Organic and inorganic geochemistry of low temperature gas discharges at the Baia di Levante beach, Vulcano Island. Italy. J. Volcanol. Geoth. Res. 108, 173-185.

Caramanna, G., Espa, S., Bouche, V., 2010. Study of the environmental effects of submarine $\mathrm{CO}_{2}$-rich emissions by means of Scientific diving techniques (Panarea Island-Italy). Int. J. of the Society for Underwater Tech. 29, 79-85.

Catsiki, V.A., Bei, F., 1992. Determination of trace metals in benthic organisms from an unpolluted area: cyclades Islands (Aegean Sea). Fresenius Environ. Bull. 1, 60-65.

Catsiki, V.A., Panayotidis, P., 1993. Copper, chromium and nickel in tissues of the Mediterranean seagrasses Posidonia oceanica and Cymodocea nodosa from Greek coastal areas. Chemosphere 26, 963-978.

Connell, S.D., Doubleday, Z.A., Hamlyn, S.B., Foster, N.R., et al., 2017. How ocean acidification can benefit calcifiers. Curr. Biol. 3, 95-96.

Conti, M.E., Tacobucci, M., Cecchetti, G., 2007. A biomonitoring study: trace metals in seagrass, algae and molluscs in a marine reference ecosystem (Southern Tyrrhenian Sea). Int. J. Environ. Pollut. 29, 308-332. https://doi.org/10.1504/ IJEP.2007.012808.

Constantini, S., Giordano, R., Ciaralli, L., Beccaloni, E., 1991. Mercury, cadmium and lead evaluation in Posidonia oceanica and Codium tomentosum. Mar. Pollut. Bull. 22, 362-363.

Conti, M.E., Bocca, B., Iacobucci, M., Finoia, M.G., Mecozzi, M., Pino, A., Alimonti, A., 2010. Baseline trace metals in seagrass, algae, and mollusks in a Southern Tyrrhenian eco- system (Linosa Island, Sicily). Arch. Environ. Contam. Toxicol. 58, 79-95. https://doi.org/10.1007/s00244-009-9331-x.

Costanza, R., Groot, de R., Sutton, P., Ploeg, S., et al., 2014. Changes in the global value of ecosystem services. Glob. Environ. Res. 26, 152-158.

Cozza, R., Laquinta, A., Cozza, D., Ruffolo, L., 2013. Trace metals in Posidonia oceanica in a coastal area of the Ionian Sea (calabria, Italy). Open J. Ecol. 3, 102-108.

Cravo, A., Foster, P., Almeida, C., Company, R., et al., 2007. Metals in the shell of Bathymodiolus azoricus from a hydrothermal vent site on the Mid-Atlantic Ridge. Environ. Int. 33, 609-615.

Dando, P.R., Stuben, D., Varnavas, S.P., 1999. Hydrothermalism in the Mediterranean sea. Prog. Oceanogr. 44, 333-367.

D'Alessandro, W., Brusca, L., Kyriakopouios, K., Michas, G., et al., 2008. Methana, the westernmost active volcanic system of the South Aegean Arc (Greece): insights from fluids geochemistry. J. Volcanol. Geotherm. Res. 178, 818-828.

Guide to best practices for ocean $\mathrm{CO}_{2}$ measurements. In: Dickson, A.G., Sabine, C.L., Christian, J.R. (Eds.), 2007, 3. PICES Special Publication, pp. 1-191.

Dickson, A.G., Millero, F.J., 1987. A comparison of the equilibrium constants for the dissociation of carbonic acid in seawater media. Deep Sea Res. 34, 1733-1743.

Dickson, A.G., 2013. Certificate of Analysis. Reference Materials for Oceanic $\mathrm{CO}_{2}$ Measurements. University of California, San Diego.

Di Leo, A., Annicchiarico, N., Cardellicchio, L., 2013. Trace metal distribution in Posidonia oceanica and sediments from taranto Gulf (Ionian Sea, southern Italy) Mediterr. Mar. Sci. 14, 204-213.

Dong, Y., Rosenbaum, R.K., Hauschild, M.Z., 2016. Assessment of metal toxicity in marine ecosystems; comparative toxicity potentials for nine cationic metals in coastal water. Environ. Sci. Technol. 50, 269-278.

Enochs, I.C., Manzello, D.P., Donham, E.M., Kolodziej, G., et al., 2015. Shift from coral to macroalgae dominance on a volcanically acidified reef. Nat. Clim. Chang. 5, 1083-1088.

EPA, 2007. Framework for Metal Risk Assessment. U.S Environmental Protection Agency. Office of the Science Advisor, Washington D.C.

Fergusson, J.E., 1990. The Heavy Elements' Chemistry, Environmental Impacts and Health Effects. Pergamon Press, Oxford, UK.

Fourqurean, J.W., Duarte, C.M., Kennedy, H., Marbà, N., et al., 2012. Seagrass ecosystems as a globally significant carbon stock. Nat. Geosci. 5, 505-509.

Gabianelli, G., Gillot, P.Y., Lanzafame, G., Romagnoli, C., et al., 1990. Tectonic and volcanic evolution of Panarea (Aeolian islands, Italy). Mar. Geol. 92, 313-326.

Govers, L.L., Lamers, L.P.M., Bouma, T.J., Eygensteyn, J., 2014. Seagrasses as indicators for coastal trace metal pollution: a global meta-analysis serving as a benchmark, and a Caribbean case study. Environ. Pollut. 195, 210-217. https://doi.org/10.1016/j. envpol.2014.08.028. 
Hall-Spencer, J.M., Rodolfo-Metalpa, R., Martin, S., Ransome, E., et al., 2008. Volcanic carbon dioxide seeps show ecosystem effects of ocean acidification. Nature 454, 96-99.

Hodkinson, R.A., Cronan, D.S., Varnavas, S., Perissoratis, C., 1994. Regional geochemistry of sediments from the hellenic Volcanic Arc in regard to submarine hydrothermal activity. Mar. Georesour. Geotechnol. 12, 83-129.

Ivanina, A.V., Sokolova, I.M., 2015. Interactive effects of metal pollution and ocean acidification on physiology of marine organisms. Cur. Zool. 64, 653-668.

Kadar, E., Costa, V., Segonzac, M., 2007. Trophic influences of metal accumulation in natural pollution laboratories at deep-sea hydrothermal seeps of the Mid- Atlantic Ridge. Sci. Total Environ. 373, 464-472.

Kabata-Pendias, A., Mukherjee, A.B., 2007. Trace Elements from Soil to Human. Springer, Berlin, Heidelberg.

Kadar, E., Fisher, A., Stolpe, B., Harrison, R.M., et al., 2012. Metallic nanoparticle enrichment at low temperature, shallow $\mathrm{CO}_{2}$ seeps in Southern Italy. Mar. Chem. 140, 24-32.

Koch, M., Bowes, G., Ross, C., Zhang, X., 2013. Climate change and ocean acidification effects on seagrasses and marine macroalgae. Glob. Chang. Biol. 19, 103-132.

Lacoue-Labarthe, T., Martin, S., Oberhansli, F., Teyssie, J.L., et al., 2009. Effects of increased $\mathrm{pCO}_{2}$ and temperature on trace element ( $\mathrm{Ag}, \mathrm{Cd}$ and $\mathrm{Zn}$ ) bioaccumulation in the eggs of the common cuttlefish, Sepia officinalis. Biogeosciences 6, 2561-2573.

Lacoue-Labarthe, T., Martin, S., Oberhansli, F., Teyssie, J.L., et al., 2012. Temperature and $p \mathrm{CO}_{2}$ effect on the bioaccumulation of radionuclides and trace elements in the eggs of the common cuttlefish, Sepia officinalis. J. Exp. Mar. Biol. Ecol. 413, 45-49.

Lafabrie, C., Pergent-Martini, C., Pergent, G., 2008. Metal Contamination of Posidonia oceanica meadows along the Corsican coastline (Mediterranean). Environ. Pollut. $151,262-268$.

Lau, S., Mohamed, M., Tan Chi Yen, A., Suut, S., 1998. Accumulation of heavy metals in freshwater molluscs. Sci. Total Environ. 214, 113-121.

Lauritano, C., Ruocco, M., Dattolo, E., Buia, M.C., et al., 2015. Response of key stressrelated genes of the seagrass Posidonia oceanica in the vicinity of submarine volcanic vents. Biogeosci. Discuss. 12, 4947-4971.

Lemasson, A.J., Fletcher, S., Hall-Spencer, J.M., Knights, A.M., 2017. Linking the biological impacts of ocean acidification on oysters to changes in ecosystem services: a review. J. Exp. Mar. Biol. Ecol. 492, 49-62.

Llagostera, I., Pérez, M., Romero, J., 2011. Trace metal content in the seagrass Cymodocea nodosa: differential accumulation in plant organs. Aquat. Bot. 95, 124-128.

Lewis, M.A., Devereux, R., 2009. Non-nutrient anthropogenic chemicals in seagrass ecosystems: fate and effects. Environ. Toxicol. Chem. 28, 644-661.

Lewis, C., Ellis, R.P., Vernon, E., Elliot, K., et al., 2016. Ocean acidification increases copper toxicity differentially in two key marine invertebrates with distinct acid-base responses. Nature $6,1-10$.

Long, E.R., MacDonald, D.D., 1998. Recommended uses of empirically derived, sediment quality guidelines for marine and estuarine ecosystems. Hum. and Ecol. Risk Assess. 4, 1019-1039.

MacDonald, D.D., Carr, R.S., Calder, F.D., Long, E.R., et al., 1996. Development and evaluation of sediment quality guidelines for Florida coastal waters. Ecotoxicology 5, 253-278.

MacDonald, D.D., Lindskoog, R.A., Smorong, D.E., Greening, H., et al., 2000. Development of an Ecosystem-Based Framework for Assessing and Managing Sediment Quality Conditions in Tampa Bay, Florida. Tampa Bay Estuary Pro- gram, Florida, USA.

Malea, O., Haritonidis, S., 1999. Cymodocea nodosa (ucria) aschers. As a bioindicator of metals in thermaikos Gulf, Greece, during monthly samplings. Bot. Mar. 42, 419-430.

Malea, P., Kevrekidis, T., 2013. Trace element (Al, As, B, Ba, Cr, Mo, Ni, Se, Sr, Tl, U and V) distribution and seasonality in compartments of the seagrass Cymodocea nodosa. Sci. Total Environ. 463, 611-623.

Mehrbach, C., Culberson, C.H., Hawley, J.E., Pytkowicz, R.M., 1973. Measurements of the apparent dissociation constants of carbonic acid in seawater at atmospheric pressure. Limnol. Oceanogr. 18, 897-907.

Milazzo, M., Rodolfo-Metalpa, R., Chan, V.B.S., Fine, M., et al., 2014. Ocean acidification impairs vermetid reef recruitment. Sci. Rep. 4, 4189.

Milazzo, M., Alessia, C., Quattrocchi, F., Chemello, R., D'Agostaro, R., Gil, J., Vaccaro, A. M., Mirto, S., Gristina, M., Badalamenti, F., 2019. Biogenic habitat shifts under longterm ocean acidification show nonlinear community responses and unbalanced functions of associated invertebrates. Sci. Total Environ. 667, 41-48.

Millero, F.J., Woosley, R., DiTrolio, B., Waters, J., 2009. Effect of ocean acidification on the speciation of metals in seawater. Oceanography $22,72-85$.

Nicolaidou, A., Nott, J.A., 1998. Metals in sediment, seagrass and gastropods near a nickel smelter in Greece: possible interactions. Mar. Pollut. Bull. 36, 360-365.

Nogueira, P., Gambi, M.C., Vizzini, S., Califano, G., et al., 2017. Altered epiphyte community and sea urchin diet in Posidonia oceanica meadows in the vicinity of submarine volcanic $\mathrm{CO}_{2}$ vents. Mar. Environ. Res. 127, 102-111.

Nordlund, M., Koch, E.W., Barbier, E.B., Creed, J.C., 2016. Seagrass ecosystem services and their variability across Genera and Geographical regions. PLoS One 12, e016994.

Olivé, I., Silva, J., Lauritano, C., Costa, M.M., et al., 2017. Short term responses of seagrasses exposed to $\mathrm{CO}_{2}$ in volcanic vents. Sci. Rep. 7, 42278.

Pascal, P.Y., Fleeger, J.W., Galvez, F., Carman, K.R., 2010. The toxicological interaction between ocean acidity and metals in coastal meiobenthic copepods. Mar. Pollut. Bull. 60, 2201-2208.

Pergent, G., Pergent-Martini, C., 1999. Mercury levels and fluxes in Posidonia oceanica meadows. Environ. Pollut. 106, 33-37.
Pierrot, D., Lewis, E., Wallace, D.W., 2006. MS excel program developed for $\mathrm{CO}_{2}$ system calculations program developed for $\mathrm{CO}_{2}$ system calculations. ORNL/CDIAC-105a. (Carbon Dioxide Information Analysis Centre. Oak Ridge National Laboratory, US Department of Energy.

Prange, J.A., Dennison, W.C., 2000. Physiological responses of five seagrass species to trace metals. Mar. Pollut. Bull. 41, 327-336.

Ralph, P.J., David, T., Kenneth, M., Stephanie, S., et al., 2006. Human impacts on seagrasses: eutrophication, sedimentation, and contamination. In: Larkum, A.W.D., Orth, R.J., Duarte, C.M. (Eds.), Seagrasses: Biology, Ecology and Conservation. Springer, Dordrecht, The Netherlands, pp. 567-593.

Renzi, M., Teresa, R., C, G., Guido, P., Italianod, S.E., et al., 2011. Temporal trends and matrix-dependent behaviors of trace elements closed to a geothermal hot-spot source (Aeolian Archipelago, Italy). Proced. Earth Planetary Sci. 4, 10-28.

Riba, I., Delvalls, T.Á., Forja, J.M., Gómez-Parra, A., 2004. The influence of pH and salinity on the toxicity of heavy metals in sediment to the estuarine clam Ruditapes philippinarum. Environ. Toxicol. Chem. 23, 1100-1107.

Richards, R., Chaloupka, M., Sano, M., Tomlinson, R., 2011. Modelling the effects of "coastal" acidification on copper speciation. Ecol. Model. 222, 3559-3567.

Richir, J., Gobert, S., 2013. The effect of size, weight, body compartment, sex and reproductive status on the bioaccumulation of 19 trace elements in rope-grown Mytilus galloprovincialis. Ecol. Indicat. 36, 33-47.

Richir, J., Salivas-Decaux, M., Lafabrie, C., et al., 2015. Bioassessment of trace element contamination of Mediterranean coastal waters using the seagrass Posidonia oceanica. J. Environ. Manag. 151, 486-499.

Richir, J., Gobert, S., 2016. Trace elements in marine environment; occurrence, threats and monitoring with special focus on the coastal Mediterranean. Env. \&Anal. Toxicol. 6, 1-19.

Roberts, D.A., Birchenough, S.R., Lewis, C., Sanders, M.B., et al., 2013. Ocean acidification increases the toxicity of contaminated sediments. Glob. Chang. Biol. 19, $340-351$.

Ruocco, M., Musacchia, F., Olive, I., Costa, M.M., et al., 2017. Genomewide transcriptional reprogramming in the seagrass Cymodocea nodosa under experimental ocean acidification. Mol. Ecol. 26, 1-19.

Russell, B.D., Connell, S.D., Uthicke, S., Muehllehner, N., et al., 2013. Future seagrass beds: can increased productivity lead to increased carbon storage? Mar. Pollut. Bull. 73, 463-469.

Sanchiz, C., Garcı-Carrascosa, A.M., Pastor, A., 2001. Relationships between sediment physico-chemical characteristics and heavy metal bioaccumulation in Mediterranean soft-bottom macrophyte. Aquat. Bot. 69, 63-73.

Sanz-Lazáro, C., Malea, P., Apostolaki, E.T., Kalantzi, I., et al., 2012. The role of the seagrass Posidonia oceanica in the cycling of trace elements. Biogeosciences 9 2497-2507.

Simpson, S.L., Angel, B.M., Jolley, D.F., 2004. Metal equilibration in laboratorycontaminated (spiked) sediments used for the development of whole-sediment toxicity tests. Chemosphere 54, 597-609.

Sternbeck, J., Östlund, P., 2001. Metals in sediments from the Stockholm region: geographical pollution patterns and time trends. Water Air Soil Pollut. Focus 1, $151-165$.

Stumm, W., Morgan, J.J., 1995. Aquatic Chemistry: Chemical Equilibria and Rate in Natural Waters, third ed.

Sunday, J.M., Fabricius, K.E., Kroeker, K.J., Anderson, K.M., et al., 2016. Ocean acidification can mediate biodiversity shifts by changing biogenic habitat. Nat. Clim. Chang. 7, 81-85.

Szefer, P., Ali, A.A., Ba-Haroon, A.A., Rajeh, A.A., et al., 1999. Distribution and relationships of selected trace metals in molluscs and associated sediments from the Gulf of Aden, Yemen. Environ. Pollut. 106, 299-314.

Tchounwou, P.B., Yedjou, C.G., Patlolla, A.K., Sutton, D.J., 2014. Heavy metals toxicity and the Environment. Mol., Clinical and Env. Toxicol. 101, 133-164.

Tedesco, D., 1996. Chemical and isotopic investigation of fumarolic gases from Ischia Island (Southern Italy): evidence of magmatic and crustal contribution. J. Vulcanol. Geother. Res. 74, 233-242.

United Nations, 2015. Transforming Our World; the 2030 Agenda of Sustainable Development. United Nations Secretariat, New York, United States.

Voltattorni, N., Sciarra, A., Caramanna, G., Cinti, D., et al., 2009. Gas geochemistry of natural analogues for the studies of geological $\mathrm{CO}_{2}$ sequestration. Appl. Geochem. 24, 1339-1346.

Vizzini, S., Tomasello, A., Maida, G.Di, Pirrotta, M., et al., 2010. Effect of explosive shallow hydrothermal seeps on $13 \mathrm{C}$ and growth performance in the seagrass Posidonia oceanica. J. Ecol. 98, 1284-1291.

Vizzini, S., Di Leonardo, R., Costa, V., Tramati, C.D., et al., 2013. Trace element bias in the use of $\mathrm{CO}_{2}$ seeps as analogues for low $\mathrm{pH}$ environments: implications for contamination level in acidified oceans. Estuar. Coast Shelf Sci. 134, 19-30.

Vizzini, S., Costa, V., Tramati, C., Gianguzza, P., et al., 2013. Trophic transfer of trace elements in an isotopically constructed food chain from a semi-enclosed marine coastal area (Stagnone do Marsala, Sicily, Mediterranean). Arch. Environ. Contam. Toxicol. 65, 642-653.

Windham, L., Weis, J.S., Weis, P., 2001. Lead uptake, Distribution and effects in two dominant salt marsh Macrophytes, Spartina alterniflora (Cordgrass) and Phragmites australis (Common Reed). Mar. Pollut. Bull. 42, 811-816.

Whitfield, A.K., 2017. The role of seagrass meadows, mangrove forests, salt marshes and reed beds as nursery areas and food sources for fishes in estuaries (Review). Rev. Fish Biol. Fish. 27, 75-110.

Yang, J., Ye, Z., 2009. Metal accumulation and tolerance in wetland plants. Front. Biol. China 4, 282-288. https://doi.org/10.1007/s11515-009-0024-7.

Zeng, X., Chen, X., 2015. The positive relation between ocean acidification and pollution. Mar. Pollut. Bull. 91, 14-21. 